Historic, Archive Document

Do not assume content reflects current scientific knowledge, policies, or practices 



\section{This Page Is Worth Reading IT CONTAINS "HOT STUFF"}

We present below a sample of many thousands of testimonials we have received for our plants and goods, during the years that we have been doing business. We never print anything but unsolicited testimonials and are sorry we have not the room for more of them.

\section{Ashland Col, Lege Y. M. C. A. Harvey Byers, A. B.}

MR. L. J. FARMER, Pulaski, N. Y.

ASHLAND, O., Oct. I5, Igog.

DEAR SIR:-In the spring of I909 I planted Iooo raspberries and Iooo blackberry plavts from you, besides several thousand strawberry plants, and all are doing exceedingly well.

Before this I have dealt with several different nurseries, but with the plants ol none have I been so successful as with yours. For this accept my heartiest thanks. Truly yours,

HARVEY BYERS.

We received the following letter a short time ago:

L. J. FARMER.

DEAR SIR:-I would like to ask you a few questions. First. Do you have a strain of strawberry plants that have bred in them a fruit producing organism of sufficient power to respond to high cultural methods? Second. Whether you fruit your propogating beds?

W. M. D., Montgomery Co., Pa.

In answer to the above or any similar communication, I wish to say that if my plants have not as much vitality and fruit producing capacity as any plants to be liad, then it is a pity. I have been growing strawberries for 27 years; have had as good yields as arybody; have sold plants to thousands of customers and they have had as good yields as anybody, but I never have tried to mislead anybody by telling them that my plants were thoroughbreds or pedigree plants, when in fact they are pedigreed or thoroughbred plants just as much as any plants produced, and will produce just as big crops as any. When anybody starts an idea, whether it is false or true, they either have to keep it going or drop it. The people who have exploited the "pedigree" idea would doubtless like to drop it like a hot potato, it is causing them enough trouble. They don't dare come out before the public and face the Agricultural Experiment Station professors and leading authorities, who all condemn the theory and laugh at it as a farce. Have any of my friends who read this catalog seen any of these "Greatest Strawberry Experts" at the Horticultural gatherings for some time? I don't pretend to be an authority on breeding, but experts tell us that there can be no permanent improvement in varieties except through the seeds. In order to improve varieties, you have to cross the blossoms and sow the seeds, then you get a new and possibly improved variety. Going around with a spy glass and pretending to select a plant with greater fruiting capacity and propogating from it to improve the variety, sounds plausable to the gullible, but there is nothing in it; and worst of all, its advocates don't believe in it themselves. They merely use it to attract attention to their goods. Nothing else sounds so plausable. What have they to say to the fact that the founder of this pedigree idea, the year before he died, tırned a big batch of orders over to a well known strawberry nurseryman to fill with whatever he had left, when the fact was this same nurseryman had never had a so called pedigree plant on his place.

\section{Some Good New Things}

Never before has such an array of good new varieties been offered the public at one time by the same firm as we offer this year. The Early Ozark, Norwood, New Discovery, Peach and Omega Strawberries, Idaho, Royal Purple and Plum Farmer Raspberries, Watt and Blowers Blackberries, Perfection Currant, Hastings Potato, etc., etc.

There never has been an extra early strawberry equal in value to the Early Ozark. It is early as Michel's Early, large as Sample and productive as Glen Mary. It will be years before anything is offered that will prove as valuable. The first person in any locality who plants it largely, will strike it rich. The same advice applies to Plum Farmer, Idaho and Royal Purple Raspberries. Our good friend, H. W. Collingwood, editor of Rural New Yorker, suggested to us the name, "Rcyal Purple" for our new raspberry.

We believe we have plenty of plants of all the above new varieties, to supply our customers. 


\section{To My Patrons}

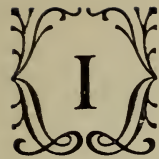

WISH to thank those who have so generously patronized me in the past and hope for a continuance of your favors. Last year was the biggest of all business years with us; we filled over 8000 orders, and we hope to do as well or even better in Igro.

Many of our friends who receive this catalogue, will also receive the cata:ogue and announcements of other firms and each has a particular argument to advance why you should purchase his goods. Many dealers rest their whole case on the fact that they undersell everybody else. I think this is the poorest argument that could be put up to a prospective buyer and I have never used it. I have always been fair in my prices, aiming to strike a happy medium between the city seedsman, who is compelled by force of circumstances to get a large price, and the man who apparently seems to be doing business just for fun. There is more in the business of selling plants and vines than merely pocketing the cash, and a good many have found this out to their sorrow. I have observed that many who start in and slash everything right and left and try to drive out of business men who have been at it a long time, soon get tired of the many exacting details and eventuaily fall by the way.

In presenting my case, I wish to say that $I$ have $b$ sen in the berry and plant business for twenty-seven years, beginning when a boy of seventeen years. That I have learned a few things in these many years of hard work among berries, goes without saying. That I am willing to give, and have given the benefit of $\mathrm{my}$ experience to others and have benefited thousands in this way, will be attested to by many friends. Could I have had the guidance and council when seventeen years of age, that I am now able to give, I am quite sure it would have saved me many mistakes. The results of my twenty-seven years of experience I freely give to prospective patrons. I never knowingly advise a patron wrongly. My kncwledge of varieties is of incalculable value. On the other hand, knowing what I do, it makes me feel badly to read the misleading literature circulated by some of my competitors, realizing as I do that it will be heeded by sume unsophisticated patron and prove a costly experience for him. There are two kinds of men engaged in the plant business, like all other kinds of business. These are the honest men and the slinks. The fellow who is trying to build up a business by downing somebody else won't succeed, and his time is short. We have to stand on our orn bottoms, and eventually will fail if we try to put out false ideas or do business on the reputation of someone else. I am in this business not merely for cash, but for other things. I like it and take pride in the fact that $I$ have been able to do a good deal of real good for my fellow men. Some men never see any farther than their own little family and farm. I am not one of these men. I like to see others succeed; I like to have others know the great truths. I do not expect, nor do I want all the business. I merely want a just share in proportion to the effort I put forth. While I have built up a big business and have great responsibilities, I am still a poor man and must have your patronage in order to succeed. I would cross the street any time and go out of my way quite a little to trade with the man whom I think needs my trade, rather than patronize the man who does not need it. I have been frank with you and hope you take the hint. Wishing you all a prosperous season in I9I0, I will close these few rambling remarks and try to get down to real business.

\section{General Information}

\section{PLEASE READ CAREFULLY BEFORE ORDERING}

\section{Prices}

In this catalogue set asile all previous quotations. They have been made as low as possible in view of general conditions. 


\section{In Ordering}

Use the order sheet and please do not wait till the last minute. Study this catalogue. If you are not clear, write us for further information. Send in your order early so we can book it and attend to the necessary details. Write letters on a separate sheet from your order. Write plainly and always sign your full name and address. Make your orders at least \$I.oo.

\section{Several People Can Club Together}

And have their orders come at the same time, addressed to one party, who can distribute them. This will save us valuable time and you express charges.

\section{Very Early in Spring}

Or late in autumn, we often sind large orders of plants long distances by freight, thereby saving our patrons express bills. We pack these orders very securely to stand the rough handling they usually get. In packing orders to go by express, we use light boxes, crates and market baskets, to save charges.

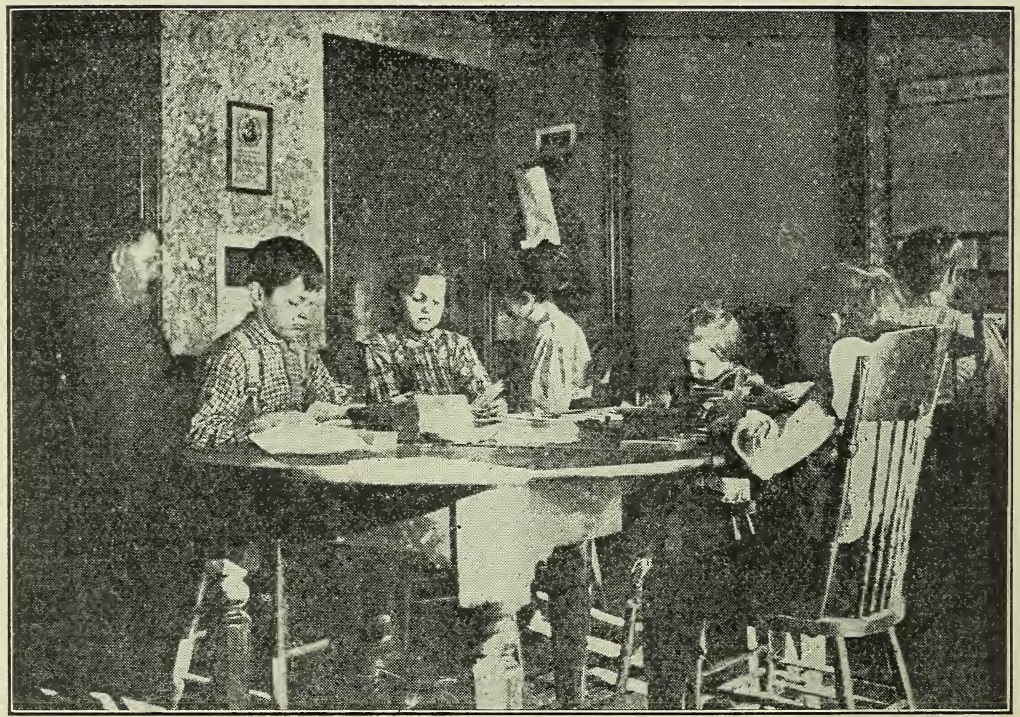

A BUSY CORNER IN OUR OFFICE-EVERYBODY WORKS.

\section{Mail Orders}

Like all other orders, are packed in damp moss. We protect the crowns of plants with cardboard and wrap all in oiled paper, coyered on the outside with strong manila. Postage on plants is 8 cents per pound to any place in the United States and we advise that small orders for long distances be sent this way. We pride ourselves on our ability to pack plants to go long distances and arrive in good condition, whether sent by freight, express or mail.

\section{Remittances}

May be made by postoffice money order, registered letter, express order, bank draft on New York (not Chicago or other cities) and bankers' money order. If you send check on local banks, add I5c for cost of collection. Don't send stamps except in small amounts of less than $\$ \mathbf{I} .00$. If you send money or stamps, register your letter. We positively will not be responsible for money sent in common letters. 


\section{Plants Collect on Delivery}

If you are short of money at the time you wish to order, or if you prefer doing business that way, we will book your order at any time, provided you send onefourth or more of the cost of the plants at time of ordering, as a guarantee of good faith; and ship the plants C. O. D., you paying for them on arrival at your express office.

\section{Plants on Credit}

Please don't ask us to open accounts in the plant business. If your credit is good, you should be able to hire money in your own town. From past experience, we have learned that very frequently plants bought on credit fail to do well. If they are paid for, the grower looks out for them and they seem to grow and do better. We don't send plants on credit except to old and tried friends who have paid promptly in the past.

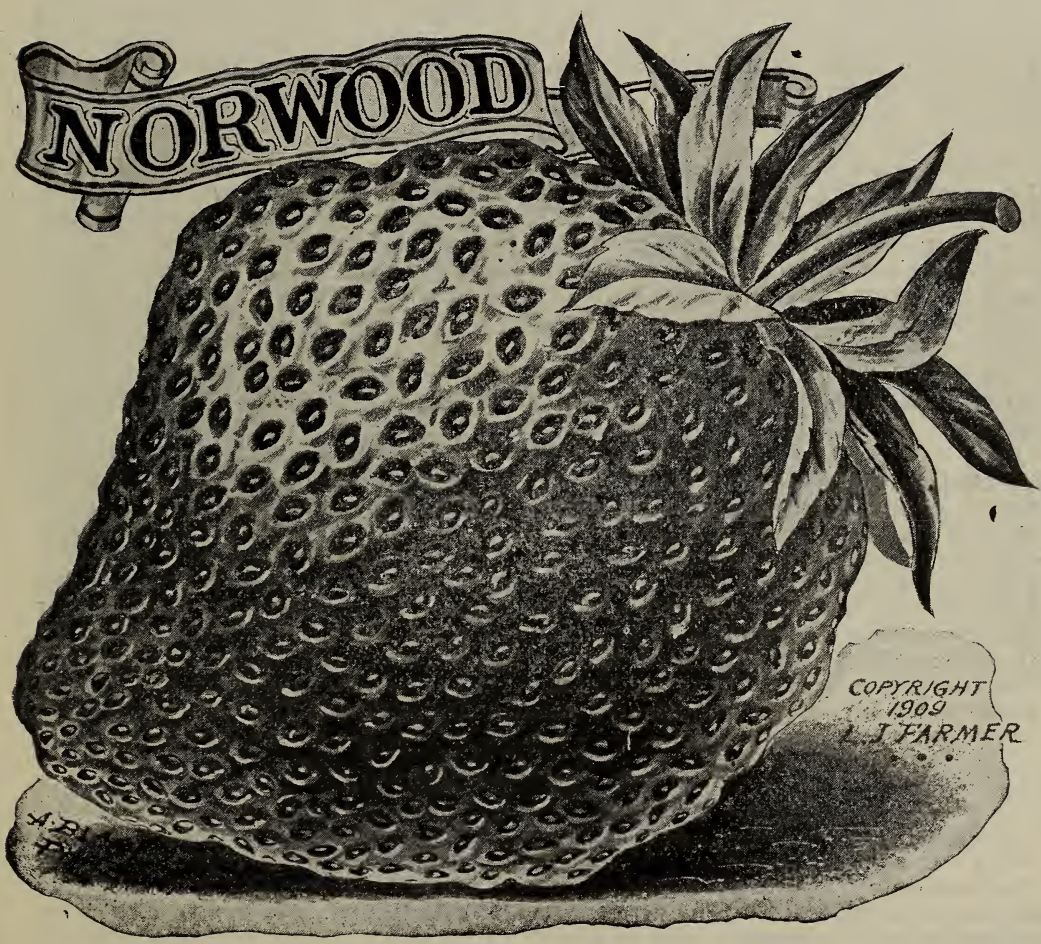

\section{You Run No Risk}

In sending money to us for plants or any kind of goods. We have been years in building up our business and are known to the public. Moreover, we could not do business continuously for so many years, or advertise in the agricultural and other papers were we not square and honest with our patrons.

\section{People With no Experience}

In the plant or berry business often leave the selection of varieties for them entirely with us. They tell us the kind of soil they have, and for what purpose the plants are wanted, and we use our best judgment, often making a better selection than is possible for those unacquainted with varieties. Merely send $\$ 1.00$, 
$\$ 5.00, \$ 10.00$ or whatever you wish to invest, giving us a general idea of what you want, and we will rack our brains for your interests.

\section{About Purity of Plants}

There seems to be a growing carelessness anong some people whom we could mention, about the mixing up of varieties. Plants will not mix except as they run across the rows or get mixed by the hand of man. We find mixed plants among even new varieties for which we have paid enormous prices. We are taking great pains to keep all varieties pure and unmixed.

\section{About Substituting Varieties}

There are several varieties of berries that closely resemble each other in general characteristics and value. Late in the season, it is often convenient for us to fill orders for certain varieties that we are sold short on, with plants of the varieties that closely resemble them. While we reserve the right to substitute a variety ordered, with other varieties as near like it as possible, we never do so except as a last resort, or when we believe it to be to the interest of the patron. In case you prefer your money returned to having your order substituted, please indicate this plainly when you order.

\section{Ours is the Latest Season}

In the United States. We are 38 miles north of Syracuse right near the bend of Lake Ontario. The ice of the lake and the west winds blowing over it, temper our climate so that vegetation does not start early. We are often a month behind Southern New York. Plants remain dormant and in shape to ship when other localities are far advanced. Strawberries are usually in full bloom May zoth. Snow sometimes covers the ground in early May, while we often begin shipping plants. early in March. We cannot ship conveniently quite as early as some localities, but we can send plants safely and they do well long after it is impracticable to ship plants from warmer localities. We fill orders for plants in large quantities the fore part of June, but advise earlier shipment, say in April and fore part of May.

\section{Our Transplanted Plants}

Are a great boon to late planters. While we advise having plants come while they are dormant, for best results, we make our own plantings mainly with transplanted plants in June and early July. We can supply customers with quantities of these plants at this time unless sold out. We take up strawberry anil raspberry plants early in April and heal them in closely together in rich garden soil and keep them watered and sprayed with Bordeaux. We find that they do not suffer the shock when transplanted to a permanent place that plants do when taken up. from the ordinary fruiting beds full of berries and covered with luxurient foliage. The transplanted plants have recovered from the shock, have little foliage, and suffer no set back when transplanted permanently, growing right along and making grand fruiting rows by fall.

\section{Summer and Fall Planting}

We snpply plants any month in the year, when possible to dig and ship them. They will do fairly well when set at any time except when in full fruit, but do best when set in March, A pril or May. For warm climates we advise fall planting. One must not expect to get as large a crop of fruit the following year if he plants in August or September as he would if he planted in April or May, but perhaps he can get more than enough fruit to pay for the trouble of caring for the plants and have them to keep over for fruiting another year. In the north we advise spring planting for commercial purposes, but there is nothing to prevent the amateur grower from planting at any time, when we consider that possibly the pleasure of growing his own berries is the most important item with him. We, however, advise and recommend the procuring of plants in late fall, no matter the loeality, and trenching them in, covering with straw, so they will be on hand and ready to plant in early spring.

\section{About Transportation}

If the order is large, so that the box is not easily lost, we advise sending all kinds of plants early in the season by freight, except strawberries and tip raspberry plants (black caps). These are liable to heat unless sent when entirely dormant. It largely depends upon the weather, anyway, it often being as warm in 
March as in some parts of May, but plants are never started much in March or early April, hence they can generally be sent safely at this time. They go by freight at first class rates, Plants by express go at regular merchandise rates, less $20 \%$. Plants by mail cost $8 \mathrm{c}$ a pound. We do not like to send by mail except in small quantities, as it is more work for us in a very busy time and they do not carry quite as nicely as in light crates or baskets by express. We charge $30 \mathrm{c}$ per 100 on strawberries for postage and packing and $75 \mathrm{c}$ per Ioo for most other plants. If you live a long distance correspond with us for rates by express.

\section{Oswego County}

Where we live is the home of the strawberry. The climate is cool and invigorating. It is a great summer resort. Plants grown in this cool climate are healthier and more heavily rooted than when grown in warmer climes. They do

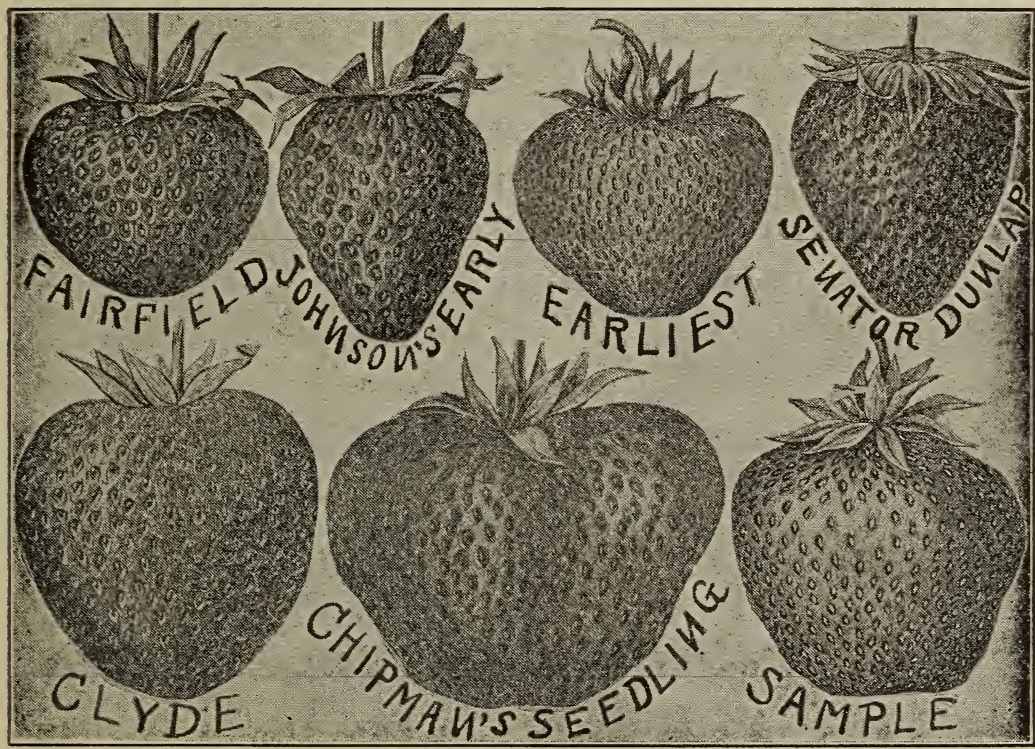

better when transplanted to other places than plants grown where the weather is always warm. The berries from Oswego county are famous and bring the highest market prices in all the great city markets of the country, New York, Boston, Philadelphia, Baltimore and even as far distant as Chicago. Our plants are like our berries-the best that can be produced.

\section{Location and Facilities}

Our farm is located one mile south of Pulaski, which is a thriving village of 2,000 inhabitants, with city water, electric lights and natural gas. We have the Bell and Black River Telephones, the Western Union and Postal Telegraphs the, New York Central Railroad and American Express. We can ship by Uuited States and Adams Express Companies from Oswego and these and other companies from Syracuse. Telegraph messages are immediately telephoned to our farm. We do business with the Pulaski National Bank.

Come and see us at any time except in the bnsy shipping season. We have absolutely no time to entertain people at this time.

Address all correspondence to L. J. FARMER, PULASKI, OswEGo Co,, N. I. 


\section{Strawberries}

It is impossible in a catalogue to give much information about the culture of berries, but my book on strawberry culture (price 25c) will give full and explicit directions. Strawberry plants produce two kinds of blossoms - the perfect and the imperfect. The perfect blossoms have all the four parts of a flower-the stamens, pistils, calyx and corolla. The varieties that have imperfect blooms lack stamens. Stamens are the male organs and pistils the female organs of the blooms. Thus a berry that has stamens is often called a "staminate" or perfect flowered, and one

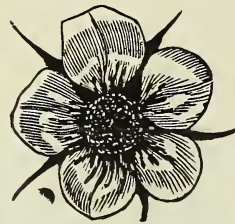

Perfect or Staminate that lacks stamens but has pistils is called a "pistillate" or imperfect flowered variety. Perfect flowered varieties can be pjanted alone and will bear good crops of berries, but pistillates,or imperfect flowered varieties, will not bear good berries when planted alone. They must have the companionship of a staminate or perfect flowered variety in order to produce perfect fruit. For practical results it is best to have them not over I 5 feet apart. The two kinds may be mixed in the rows, or alternate rows

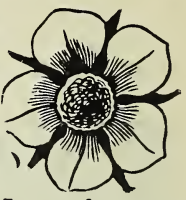

Imperfect or Pistillate planted of each variety. The closer together

the two sexes of blossoms are intermingled, the better will be the results. If we plant a patch of pure Sample, Warfield or Crescents the fruit will be seedy and mostly nubbins, but if Champion is planted near Sample, and Dunlap near Warfield and Crescent, the quantity and quality of fruit produced from these varieties will be remarkable. Varieties in this catalogue marked "per." are perfect in flower, and those marked "imp." are imperfect in flower.

\section{Brief Cultural Directions}

There is no farm crop more profitable than strawberries, no fruit more attractive or more sought for in market. You can get as much money from one acre of strawberries as is usually produced from ten acres of other crops. I have of ten said I would as lieve have the proceeds from an acre of strawberries as from ten cows. There are some crops grown by farmers that cannot possibly give one a pleasant feeling when he thinks of what they are finally made into. The tobacco grower may make as much money as the strawberry grower, but his product does not benefit the consumer, and he can think of nothing but the commercial side of the question, while the strawberry grower has the satisfaction of knowing that his product is going to do good to the consumer. It don't cost much to start in strawberry culture-about as much for an acre of plants as you would pay for an average cow. You don't have to care for strawberries during the winter; after they are covered in fall, they take care of themselves. The person who grows strawberries and has heart in his work becomes a better fellow. He is uplifted by them; he gets along better with his wife.

Any good soil that will grow either corn or potatoes, will grow strawberries. We advise planting after troo or three crops of potatoes have been grown on the same land. We advise draining thoroughly, as undrained land is us reliable, and wet induces fungous growth, the worst enemy of the strawberry. Grubs, the worst insect enemy, are largely eradicated by growing two or three crops of corn or potatoes, previous to setting the plants. We apply barn manure to the corn crofs, thus getting the manure thoroughly incorporated with the soil before setting out the plants. We use only concentrated or commercial fertilizers on the land after the plants are set, because we believe barn manures tend to cause fungous growths to flourish, to the disadvantage of the plants. We prefer, in this locality, to set plants in the spring, at the time when most other crops are put into the ground. We set in rows from 3 to 5 feet apart and the plants from $I$ to 2 feet apart in the row. A favorite distance is $\mathbf{I x} 4$ feet. Set this distance, an acre will take Io,ooo plants. We set the plants with any tool that will get the roots down straight into the soil as deep as they formerly grew. We aim to keep the ground free from weeds by horse cultivation and hand hoeing until growth stops in the fall. In applying fertilizer, our rule is to put $1 / 3$ on the ground before plants are set, $1 / 3$ while they are growing the first year, and $1 / 3$ in the spring before the growth starts, the fruitng year. We use from 500 to 2,000 lbs., depending upon the previous richness of the 
soil. The fertilizer should analyze as near $4 \%$ nitrogen, 10\% phos. acid and 10\% potash as is possible. We cover the fields with straw or some other mulch about December Ist for winter protection. This also acts as a carpet or mulch to keep the weeds down, the berries clean and trom drying up in fruiting season, if carefully removed fromover the plants and placed between the rows in early spring after severe freezing is over. We have heard of strawberry fields that have yielded nearly 50,000 quarts to the acre under special treatment and when plants are set thickly. When set in ordinary rows they have been known to go nearly 25,000 to the acre. On our farm we have had Parker Earle go 15 ooo quarts to the acre and other varieties even more. Special varieties often yield from $\$ 500$ to $\$ I, 000$ to the acre in Oswego county. The man who takes hold of the strawberry business and sticks to it for a term of years, usually pays off his mortgage and becomes well-to do. He gets more money from a few acres, has less to pay out, and no more to do than the big fellow who farms 200 acres in ordinary crops.

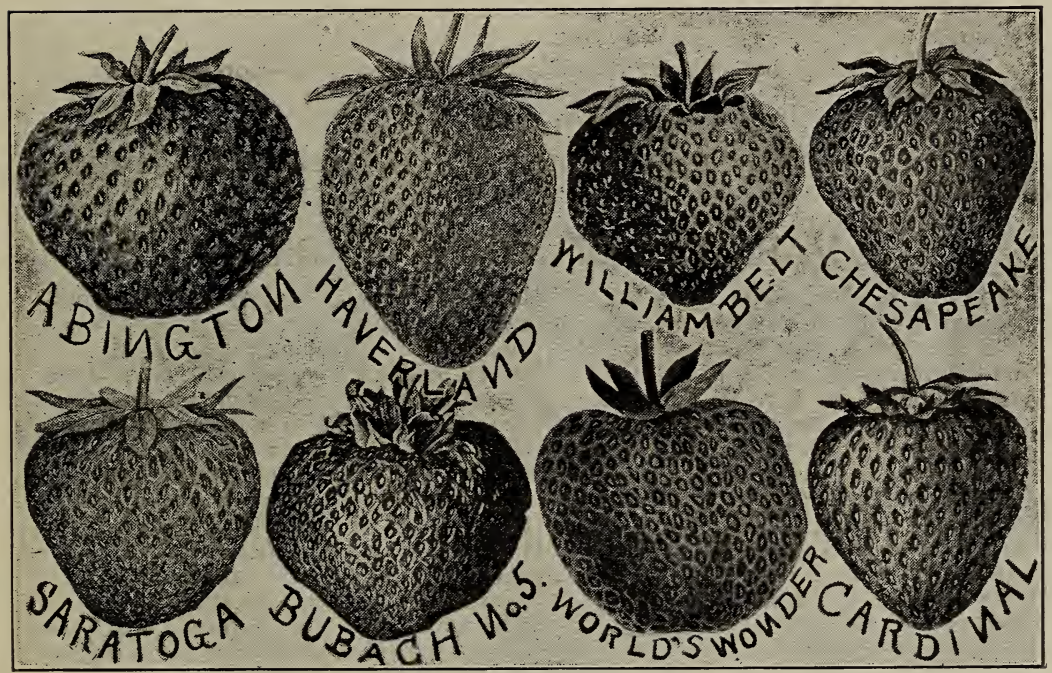

\section{IMPORTANT}

We supply 6 plants at dozen rates, 50 at Ioo; and 500 at I,000 rates, respectively. When the order amounts to $\$$ Io or more, we allow patrons to select 25 at roo rates; 250 at $\mathrm{I}, 000$ rates. All plants are sent postpaid at single and dozen prices. On large quantities the postage and packing is $30 \mathrm{c}$ per Ioo on strawberries and asparagus roots and $75 \mathrm{c}$ per 100 on raspberries, blackberries, currants, gooseberries, grapes, roses, etc. In case actual postage paid is more than this, we will add to the bill. We have to prepay all postage, and guarantee that the charges will be paid at the other end, when plants are sent by express or freight. We furnish free, all boxes, crates, baskets, oiled paper, sphagnum moss and other material used in putting up orders, which is a considerable item and often charged extra by most nurserymen.

Plants for Warm Localities

We have a quantity of plants stored in cool sheds this winter and have been shipping all through December and January to the southern states and will be able to fill small orders at any time for these localities, no matter what the weather is here in New York state.

\section{Rule For Finding Number of Plants to the Acre}

Divide 43,560 , the number of square feet in an acre, by the multiplied distance between the rows, and you will have the number of plants to the acre. Thus if the plants are set $2 \times 3 \frac{1}{2}$, you divide 43,560 by 7 , and get 6,223 , the number of plants on an acre when set $2 \times 31 / 2$ feet apart. 


\section{Extra Early Varieties}

Early Ozark, Earliest, Excelsior, Johnson's Early, Early Harvest, Virginia, August Luther, St. Louis, Oak's Early, Beeder Wood.

\section{Very Late Varieties}

Aroma, Crimson Cluster, Pride of Michigan, Gandy, Stevens' Late Champion, Cardinal, Saratoga, Chespeake, Sample, Brandywine, Parker Earle, Rough Rider, New Home, Paul Jones, Fremont Williams.

\section{Good Fertilizers}

For Haverland, Crescent, Bubach, Highland and Lady Roosevelt are Early Ozark, Earliest, Beeder Wood, Michel's Early and August Luther. For fertilizing Warfield, Mellie and other midseason varieties, use Dunlap or Chipman. For fertilizing Sample, Fendall, Paul Jones, Cardinal and other late pistillates, use BranJywine, Champion, Aroma, Saratoga, Parker Earle or Fremont Williams.

Best varieties for clay and low lands-Gandy, Rough Rider, Crimson Cluster, Johnson's Early.

Varieties doing best on light sandy or gravelly soils-Corsican, Oswego, Champion.

\section{High Class Berries}

Requiring good care, Jessie, Marshall, Sharpless, Gandy, Cooper, President and Norwood.

\section{VARIETIES OF STRAWBERRIES}

NorwOOD (Per)-The eyes of the be a cross of that variety and the Corsistrawberry world have been on the Nor- can. It is, however, a higher class berwood for two years and many are anx- ry than Marshall or Corsican, and enious to know more about it. This berry tirely distinct from either. Mr. White was originated by Mr. N. B. White, of describes it as follows: "This strawberNorwood, Mass., several years ago. It ry is supposed to be a cross of the Marras named and given the first prize over shall and Corsican, as it came up where nil others at the exhibition of the Massa- the Marshall had been grown and near chusetts Horticultural Society in 1906. where Corsican was grown at the same We bought the entire stock of plants in time. The Norwood is believed to be the spring of 1908 and whatever genuine the best strawberry in existence. The plants there are of this variety have all plant is strong and healthy, making a come originally from us. This berry has libera! number of strong runners, but not been advertised and talked about more excessive. The berry is conic and reguthan any other strawberry now in exist- lar in shape; not a coxcombed berry was ence. Many people would not believe found this season. The quality is unsurthat the pictures were true to life and passed and the size unequalled, some some have gone so far as to write the attaining the enormous size of three papers criticising them for allowing me inches in diameter. Four such berries to advertise it in their columns. Mr. would fill a box and be crowded. Color, White states to me that he never exag- bright red all the way through, growing gerates any new fruits in the photographs darker with age; is firm, a good keeper, and sends me a statement signed by his and will ship well. Has a perfect blosphotographers that the fruits are taken som and holds its size well through the true to life and of exactly the same size. season and remains in bearing a long Our experience with this variety is that time. Picked the first box June I8th, it has come up to expectations. We have and the last one July I8th. The largest not produced berries that measured three berries were found in matted row or inches in diameter, but we have grown beds, although the plants had received specimens of it the largest of any straw- no extra care."

berry we have ever seen, and we are We paid Mr. White $\$ 250.00$ in cash for quite sure that with high culture we his little bed of Norwood plants, measurcould get specimens as large as did Mr. ing about the size of a guod sized kitchen White. We have given it only ordinary floor. He had started out to sell them car: which is our rule with all new var- at \$Io per dozen, but we altered the arieties the first years of trial. The plants rangement somewhat, selling them for are of the Marshall type as are the ber- $\$ 1$ each, \$ro per dozen straight; or 25 ries, and it seems, as Mr. White says, to for \$ro, under contract. Except for the 
few that were sold by other parties last / ahead of our Excelsior last year. In size spring (I909), we know where all the as large or larger than Klondike, A roma plants of Norwood strawberry are located. or Gandy, fifteen specimen berries filling The price was reduced to $\$ 2$ per dozen; a quart rounding full. Very productive $\$ 10$ per Ioo in I909, and although the and firm, good flavor, not sour like Exsupply of plants is still limited, we have celsior; foliage large and coarse, of dark further reduced the price for spring of green color."

I 910 to $\$$ I per dozen; $\$ 5$ per Ioo; $\$ 30$ per I000.

EARLY Ozark (Per.)-This variety fruited for us the past season, and to say we were pleased and surprised, puts it too mildly. We had failed to set out a new bed of it last spring and so, after fruiting, we took up every plant and reset them, a thing we never did with any and when I say that it is as large and
other variety of strawberry. We were as productive as Sample and Glen Mary,

Our experience with this variety is that it is fully as large as Sample or Glen Mary and holds its size quite well to the close of the season. It ripened with the earliest with us and is superior to all other extra early berries. While it may possibly be somewhat later than Fxcelsior, it is fully as early as Michels Early,

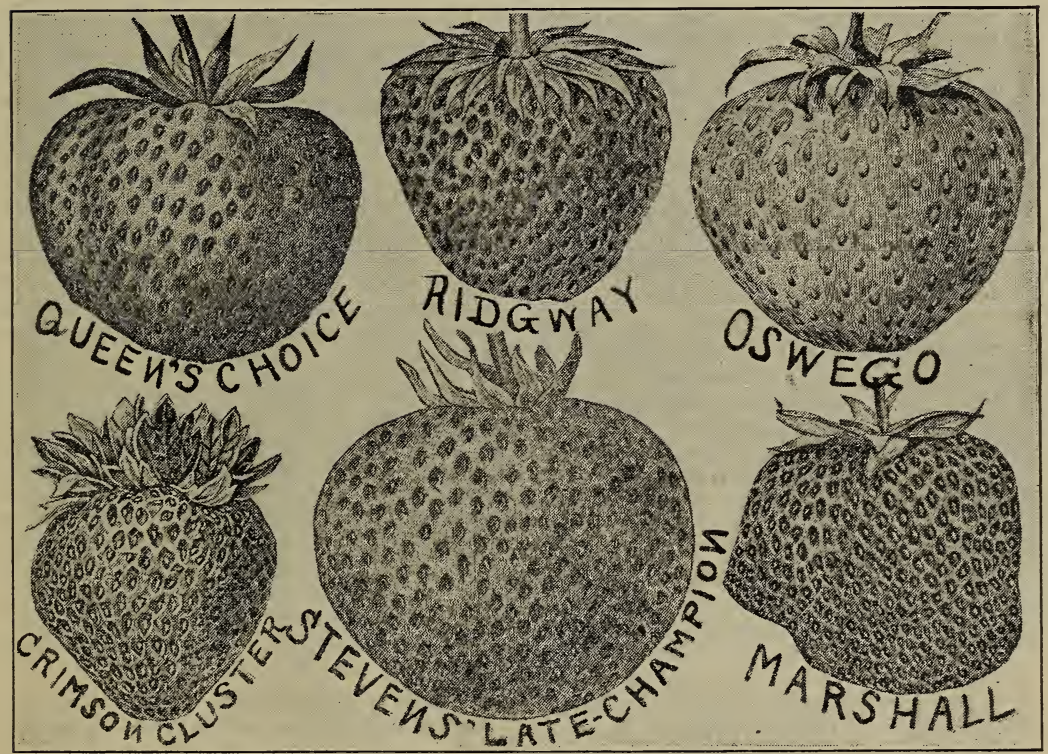

surprised to see these old fruited plants I have said enough. We believe it will start off with a vim and some of them take the place of all other earlies when made 9 new plants before winter. We the plants get well distributed. We have three fine long rows of them now, have purchased the entire stock of the and we only wish our friends and cus- originator, nearly 300,000 , and offer them tomers could see them in fruit next June. at the following very reasonable prices: It is the grandest early strawberry ever doz, 50c; I00, $\$ 2 ; 1000, \$ 10 ; 10,000, \$ 80$. introduced and will make any man rich who plants it intell.gently. It was originated by Mr. Shull, of Missouri, whu describes it as follows: "Eiarly Ozark is one of 800 seedlings I have tested. It is a cross betweer Excelsior and Aroma. It is a staminate variety with very large blossoms which are full of pollen. Early as Excelsior or Michels Early, ripened

OsweGo (Per.) - This variety originated in our county and was introduced by us a few years ago. It has proved to be a very valuable variety. The plants and fruit are of the Corsican or Uncle Jim class but seem to be more valuable and reliable than either of those varieties. The plants are light green in color, make large crowns and produce immense crops 
of fruit, even on comparatively poor soils. It seems to bear better crops the second year even than the first. Some of my friends who have fruited it, claim that there will be double the number of fruit stems the second year that existed the first. It certainly has distinguished itself as a great variety for poor soils and fruiting continuously on the same ground for several years. The fruits are large, oblong in shape and of a light scarlet color. The berries are mild in flavor and highly esteemed by most people. It is one of the largest berries and greatest yielders in existence and grows in popularity every year in this locality. Doz, 30; IOO, \$I; IOOO, \$6.

Senator DunlaP (Per.)-This variety is recommended for the average person who wishes to grow strawberries and has had little experience. It is a very vigorous grower and the berries are of good flavor, good canners and excellent shippers. If given only ordinary care the yield will be large and the quality of fruit fair. If the runners are thinned and high culture is given, some of the finest fruits possible to grow can be produced of this variety. It ripens quite early and is classed as a mid-season. Doz, 25c; I0o, 60c; I000, $\$ 4.50$.

STEVENS' LATE Champion.-This is among late varieties of strawberries what Senator Dunlap is among mid-season varieties. It is a great runner and the plants are entirely healthy. The fruit is large, firm, of good color and produced in great abundance. In this locality it is the great popular late variety. The fruit ripens above the foliage and as one approaches a field of them, he is reminded of a great flower garden, when seeing the plants laden with red fruit. It is a good keeper and one does not have to hurry to pick them. I unhesitatingly recommend it. Doz, 25c; 100, 60c; 1000, $\$ 5$.

Chipman's Seediling (Per.)-On our soil this is a good grower, the plants tending to grow close to the ground like Clyde. The fruits are extra large, light scarlet in color and produced in immense quantities. One of my neighbors who had a large number of varieties, states it was her best variety for profit the past season. In Delaware where it originated, it is much thought of, being planted in large quantities. Doz, 25c; IOO, 6oc; 1000, $\$ 5$.

EXCELsIor (Per.)-This is undoubtedly the very earliest strawberry in existence. It is a great runner and must be kept restricted to narrow rows for best results. If the plants are not crowded too much, the yield will be large and the berries fine. The fruit is of a deep, rich, dark color, very glossy, attractive and firm and sells well in market. It is good for canning, reminding one of the old Wilson. In warm, early locations there is good money in growing Excelsior. Doz, 25c; 100, 50c; Iovo, $\$ 4$.

SAMPLE (Imp.)-This is one of the popular old standbys. The plants are good average growers, covering the soil with medium sized plants, just about thick enough. The fruit is very large, dark in color and very firm. The plants are enormously productive and do finely on most all kinds of soils. It ripens midseason to late. It should have a good staminate planted close by it. Doz, 25c; IOO, 60c; IOOO, $\$ 5$.

WARFIELD (Imp.) - This variety is one of the best shipping and canning berries in existence. The plants are small but very vigorous and great runners, covering the surface with a mesh of plants. It should be restricted for best results. It does best on a rich moist soil when properly pollenated with some other variety blossoming at the same time. The berries are very dark, glossy, firm and attractive, of good flavor. They ripen early for a mid-season variety. It has the record of being the most productive variety in existence. Doz, 25c; 100, $60 c$; $1000, \$ 4$.

MARSHAL, (Per.)-This is a good grower of fine, light colored plants. It is classed as a blooded berry. By this we mean that it must have good culture to do its best. The fruits are very dark, glosšy, crimson in color, exceptionally attractive, and of the very finest flavor. No use of the slovenly grower trying to get satisfactory crops of Marshall. I have seen six berries that more than filled a quart basket. It ripens quite early. Doz, 3oc; Ioo, $\$ \mathrm{I}$; 1000, $\$ 6$.

AROMA (Per.) - This variety is growing in popularity every year. Its territory is not confined to any one locality, but it seems to succeed most everywhere. The plants are good strong growers and produce good crops of very large, dark colored, firm berries of excellent quality. It ripens medium to late and continues very late. An excellent berry to fertilize late pistillates as well as a good berry itself. Doz, 25c; I00, 6oc; I000, $\$ 5$.

CRIMSON CluSTER (Per.)-A splendid berry of the Gandy type, but seems to be an improvement on that famous variety. Doz, 25c; 100, 6oc; 1000, $\$ 5$.

BUBACH (Imp.)-This is one of the largest berries ever grown. It is very early, light colored, only fairly firm, and 
of fair quality. It produces an immense attractive that the berries always sell for crop early in the season which will sell good prices. Doz. 25c; 100, 60c; 1000, \$5.

well on account of immense size. It slould be pollenated with Beeder Wood or some medium early variety. Doz, 25c; 100, 75c; 1000, \$6,

CLYDE (Per.) - This is a very valuable berry on soil adapted to its growth. It is quite similar to Bubach in many ways, but is perfect in flower. It is a dry soil, dry season berry and won't do well in rainy weather or on low, damp land. Its foliage is often lacking, especially in soils unfitted for its growth. It is the most productive large berry I have ever seen. Doz, 25c; 100, 75c; I000, \$6.
SPLENDID (Per.)-This variety is a rough and ready strawberry, doing its best under partial neglect or when not allowed to grow too thick in the rows. The plants are models of growth, being healthy, glossy and of fne appearance. The berries are medium to large, round, dark red in color and very firm. It ripens midseason, is very productive and firm. Doz. 25c; 100, 60c; I000, \$5.

LADY ROOSEVELT (Imp.) - This is a rough and ready variety that will please the person who gives careless culture. It is quite early, very productive, of fine

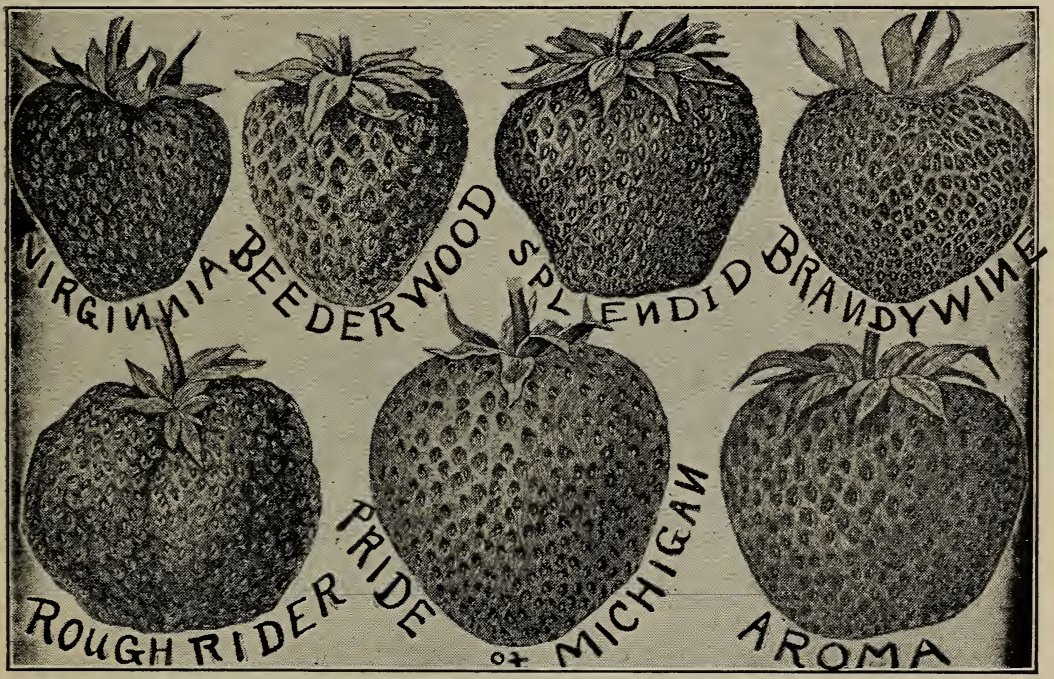

EARLIEST (Per.) - This is very easily / color and flavor and of medium size. The grown as it will cover the ground with plants are very vigorous runners and plants when once it gets a start. I does cover the ground with only ordinary care, best when allowed to run wild the year It should be fertilized with Beeder Wood. of setting, merely pulling the weeds Doz. 25c; 100, 60c; 1000, $\$ 5$.

after the first hoeing. It is fairly productivs of fine flavored berries of medium size. It will remain of finest quality even during wet, sour spells of weather wh'n other varieties get sour. It ripens very early, possibly five minutes after the Excelsior. Doz. 25c; 100, 60c; I000, $\$ 5$.

GaNDy (Per.) - This is the standard late variety of the United States. The plants are fair growers, having long jointed runners which readily distinguish them from most other varieties. The fruit ripens very late, is large, dark dull red in color and produced in moderate

COOPER (Per.) -This is a high class berry, superior to Nick Ohmer, which it resembles in fruit. The plants are good growers, being yellowish in color. The fruits are medium to large, very fine flavored, deep red in color, glossy and attractive. Must have high culture. Doz. 25c; 100, 60c; I000, $\$ 5$.

UNCLE JIM (Per.)-This variety ${ }^{\top}$ produces large, heavy, light colored plants, which are models of growth and very productive of very large, light, salmon colored berries of mild agreeable flavor. It is in favor with many growers because amount. It ripens so late, is so firm and of immense size and productiveness. Doz. 
50c; 100, \$1; 1000, \$7.

HUMMER (Per.) Doz. 25c; IOO, 60c; IOOO, $\$ 5$.

BRANDYwINE (Per.)-This variety is in favor with many growers, while with others it is not. It is somewhat erratic in its behavior, producing a large crop of the finest colored and largest berries with some and a small crop of dull, dark colored berries with others. When it succeeds it is unsurpassed. The plants are good growers. Ripens very late. Doz, 25c; 100, 75c; 1000, $\$ 6$.

SARATOGA (Per.)-This variety produces an inmense crop of large, irregular shaped berries of rich dark color, not very attractive nor of fine flavor. The plants are good growers, very vigorous and hardy. Doz, 25c; IOO, 60c; IOOO, $\$ 5$.

HAVERLAND (Imp.)-This is one of the old standbys, doing especially fine when planted on soil with clay in its makeup. The plants are fair growers and yield so heavily that someone described them as producing berries in great heaps and piles. The berries are long, light colored, not very firm, but glossy and attractive to the eye, having a very small calyx, so that the berry itself is not hidden. It often produces a good crop of fruit late in autumn as well as in spring. It ripens quite early. Doz, 25c; I00, 75c; I000, $\$ 6$.

JESSIE (Per.)-This berry is noted for its fine quality. The plants are large and fairly productive of the largest sized berries. The fruit is dark colored, very rich and meaty. Doz. $25 \mathrm{c}$; 100, $75 \mathrm{c}$; 1000, $\$ 6$.

Pride of Michigan (Per.)-This is a very large, late strawberry which is in great favor among the people of its native state. We have not yet fruited it but the plants are fine. Doz. $25 \mathrm{c}$; IOO, $75 \mathrm{C}$; IOOO, $\$ 6$.

THREE W's (Per.)-We have not fruited this famous variety, although it makes a good appearance with us. Doz. 25c; IOO, 60c; IOOO, $\$ 5$.

ABINGTON (Per.)-This berry is all that was ever claimed for it. For years it has been a favorite at Maplewood Fruit Farm, where our pickers prefer it to most others. It is very large, bright scarlet in color, smooth and enormously productive. The plants are models of growth. It ripens very early, soon after the extra early ones and continues for a long time. It is very large and superior to Bubach for market. Doz. 25c; 100, 75c; 1000, $\$ 6$.

WM. BELT (Per.) - This variety is rather erratic, being in great favor with some and in disrepute with others. The plants are good growers and seem to produce a better crop the second year than the first. The berries are large, rather irregular and of the very finest flavor. I advise my friends to experiment with this variety if they have not already done so. Doz. 25c; 100, 75c; 1000, $\$ 6$.

CHESPEAKE (Per.)-I hate to sound the death knell to any variety, but the Chespeake is of no particular value with us. They tell me it is a grand variety in Maryland, but with us, while it produces very large, fine specimens. there are not enough of them. The plants are immense growers, great runners aud individual plants are extra large and fine. Doz, 25c; Ioo, 75c; I000, $\$ 6$.

CoRsican (Per.) - This variety belongs to the same general type of strawberries as Oswego and Uncle Jim or Dornan. It produces an immense crop of light scarlet berries which are inclined to be rather light colored on the under side. The flavor is mild, not very rich but agreeable to most tastes because of lack of pronounced acid. The plants are fine growers. It does especially well on sand and gravel and is so well thought of by many that it goes under several names, such as Armstrong, German Seedling, Morgan's Favorite, \&c., \&c. Doz. 25c; I00, $75 \mathrm{c}$; I000, $\$ 6$.

KLONDIKE (Per.)-This is a good grower and produces a fine crop of light colored fruits of good size and very regular shape, appearing as if turned in a machine. Does especially fine in the south. Doz. 25c; 100, 50c; 1000, $\$ 4$.

WILSON (Per.)-The old stand by. fine for canning and shipping, rich dark color, acid and of good quality. Doz. $25 \mathrm{c}$; IOO, $75 \mathrm{c}$; 1000, $\$ 6$.

JOHNSON'S EARLy (Per.) -This is one of the extra early varieties, ripening with Earliest, that does well on heavy soils. The plants are great runners and mat too thickly unless thinned. The berries are deep red in color, very firm and attractive, being long in shape with little hull. Doz. 25c; IOO, 75c; IOOO, $\$ 5$.

PARKER EARLE (Per.)-One of the old stand bys. It has produced the largest crop of berries witl us, we ever saw grow. The plants are immense, bushy in form with few runners and simply out do themselves in productiveness. The fruits are medium sized, long in shape and not very attractive. It ripens very late and lasts until most others are gone. It was the most productive of any variety with us the past season. Doz. 50c; I0o, $\$ \mathrm{I} ; 1000, \$ 8$.

PAN AMERICAN (Per.)-This variety produces a crop of berries any growing 
month in the year, provided the blossoms are kept cut until about three weeks before you wish them to fruit. They start in to blossom in the spring and will produce a crop of fruit then if blossoms are not cut. If kept off until August or September, the blossoms will keep coming out and can then be allowed to mature a crop of fruit. It is just as persistent in bearing fruit in the fall as other varieties are in the spring, in fact, it is liable to bear itself almost to death if all blossoms are allowed to mature fruit. This is a very interesting variety, a sport from the old Bismark strawberrv and has revolutionized the strawbery busincss. Until the Pan American, thicre was no such thing as a practical fall bearing strawberry. The plaints are stu:dy gromers but produce very fer runners and this is why plants are so cosily. We have secured a large stock and now offer them at a reduced price. Doz. \$I.75; IO0, SIo.
Sharpless (Per.)-We have a stock of this old favorite. If quality, size and productiveness are wanted try Sharpless. Doz. 25c; I0o, 75c; 1000, $\$ 6$.

Dicky (Per.)-We find nothing in this to commend after two years trial. Doz. $25 \mathrm{c}$; 100, 75; 1000, $\$ 6$.

GoldeN GATE (Per.)-This variety did fine for us the past season. The fruit was extremely large, dark red, glossy and attractive. One of the most productive and valuable we ever fruited. Plants suffered some from rust but we are highly pleased, just the same. Doz. 50c; 100, \$2; 1000, \$10.

Nichol's GRaNville (Per.)-A high class berry, large, fine, good flavor. Doz. 25c; 100, 6oc; 1000, $\$ 5$.

CRESCENT (Imp.)-Plants great runners, berries produced in immense quantities. Color light scarlet. The old favorite for quantity. Doz. $25 \mathrm{c}$; IOO, 50c; I000, $\$ 4$.

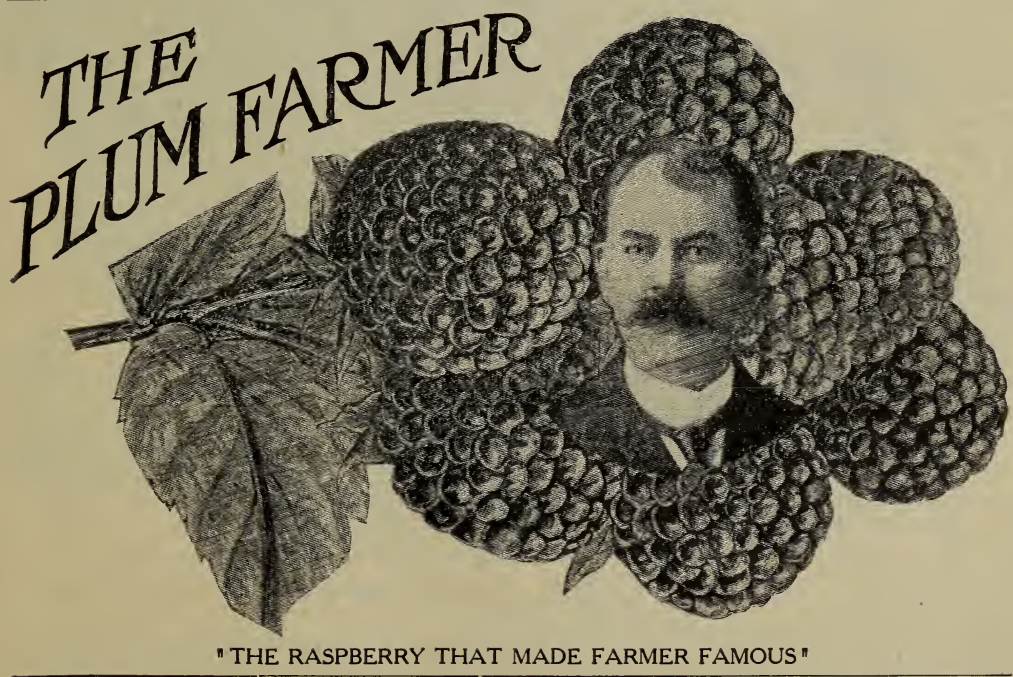

A UTUMN (Imp.) -A pistillate fall bearing strawberry, not as large as Pan American, but immense in productiveness, of to be even superior to that grand extra fine regular form and deep red color. It early variety. Doz. 25c; 100, 60c; Iooo, produces plenty of runners. Doz. $50 c ; \$ 5$. IOO, \$2.50; IOOO, \$I5.

WINCHELI'S BEAUTY (Per)-One of the finest berries in cultivation. Plants are large fine growers, almost perfect in appearance. Berries are large, reg-lar It is very similar to the old Ridgway in form, very bright and glossy, immensely general value. Doz. 25c; I00, 75c; I000, productive, very late. Doz. 50c; 100, \$I; $\$ 6$. was our leader. It is a fine grower, the
plants having roots as bright and healthy

RIDGWAy (Per)-When we used to grow so many berries for market, this was our leader. It is a fine grower, the Iooo, \$8. 
EDGAR QUEEN (Imp.)-A very productive midseason variety of good color and of good size. The plants are good growers and fully able to mature a large crop of fruit. Doz. 25c; I00, 60c; 1000, $\$ 5$.

BEEDER WOOD (Per.)-This excellent old variety is still in great favor. The plants are good runners and produce immense crops of fruit which ripen real early, just after extra earlies. The fruit is medium to large, light colored and quite attractive. Where light si arlet berries are in demand, Beeder Wood is very popular. Doz. 25c; 100, 60c; I000, $\$ 5$.

Rough RIDER (Per.)-This variety was introduced by us several years ago. The plants are sturdy rugged growers and produce large crops of fruit very late in the season. The fruits are large, very firm, dark red in color, solid a)l the way through and very firm, an excellent shipper and canner. This variety is becoming more popular every succeeding year. Doz. 50c; IOO, $\$ \mathrm{I}$; IO00, $\$ 8$.

NEW DISCOVERY (Per.)-This variety comes from the originator of the Royal Purple raspberry, who claims it to be the best rough and ready berry that he has ever seen. The plants are very strong and vigorous growers. Mr. Girton claims that the New Discovery is a better berry than the Dunlap and holds its size well to the end of the season, ripening early to mid-season. We have not yet fruited it, but the plants show strong characteristics. Doz, $\$ 2$; IOO, $\$ 10$.

PEACH (Per.)-Also from Mr. Girton. A berry of the Bubach type, said to be a great improvement on the Bubach. Doz, \$2; IOO, \$10.

OMEGA (Per.)-Another berry from Mr. Girton, claimed by him to be the latest as well as the best late berry. All of the above three berries are crosses of the Capt. Jack, with the object of getting the golden seeds of that variety combined with desirable characteristics of other varieties. Doz, $\$ 2$; IOo, $\$$ Io.

NOTE - We will send one dozen plants each of New Discovery, Peach and Omega for $\$ 5$ If after fruiting them, you are not satisfied, you can select $\$ 5$ worth of other plants from our catalogue to reimburse you.-L. J. F.

SUCCESS.-One of the most valuable of early to mid-season varieties. The plants are model growers, very healthy and productive. The berries are very large, bright red, attractive and desirable for home use or market. We have a fine stock of this grand variety. Doz, $25 \mathrm{c}$; I00, 60c; I000, $\$ 5$.
MCKINLEY (Per.) - A light scarlet berry of great value; very large and productive. Doz, 25c; 100, 75c; 1000, $\$ 6$.

RED BIRD (Per.) Not fruited. Doz, 25; IOO, 5Oc; IOOO, $\$ 4$.

MICHEL'S EARLX (Per.) -The standard extra early. Doz, 25c; Ioo, 60c; 1000, $\$ 5$.

WORLD'S WONDER-Doz, 25c; IOO, 75c.

FAIRFIELD (Per.)-Doz, 25c; IOO, 75c.

Cardinal (Imp.)-We had this listed last year by mistake, as a perfect flowered variety. It is a strong, hardy grower, making large plants and plenty of them. The fruits are larye, dark red in color and very firm. This is highly recommended by most authorities. Doz. 25c; IOo, 60c; IOOO, $\$ 5$.

GLEN MARY (Per.)-This is listed as a perfect flowered variety but its stamens are rather weak and the variety does best when planted close by some strong flowering variety that blooms at the same time. The Glen Mary is in great demand on account of its large size, great firmness and enormous productiven ss. The fruits are inclined to be white tipped and the qualily is quite poor, but it is in great favor with growers because it gets there with the quarts. Doz. $25 \mathrm{c}$; IOO, $75 \mathrm{c}$; I000, $\$ 6$.

Bountiful (Per) - A New Jersey production. Doz. 25c; 100, 75c; 1000, $\$ 6$.

IDAHO STRAWBERRY (Per.)-Doz. 5Oc; IOO, $\$ 2$.

FENDALL (Imp.)-Doz. 50c; IOO, \$2; IOOO, \$15.

BUSTER-Doz. 25c; IOO, $60 \mathrm{c}$.

Poсомоке-Doz. 25c; 100, 6oc.

PRESIDENT (Per.)-Doz. 25c; IOO, 75c; IOO0, $\$ 6$.

OAK'S EARLY (Per.)-Doz. 25c; IOO, 6oc.

MEAD (Per.)-Doz. 25c; IOO, 6oc.

NORTH SHORE (Per.)-Doz. 25c; IOO, $60 c$.

St. Louis (Per.)-Doz. 25c; 100, 60c.

HIGHLAND (Imp.)-Doz. 50c; IOO, \$2; IOOO, \$IO.

PAUl JoNES (Imp.)-Doz. 50c; IOO, \$2. MELLIE (Imp.)-Doz. 25c; IOO, 6oc.

Jim Dumas (Per.)-Doz. 25c; Ioo, 6oc. EARLY HARVEST (Per.)-Doz.5Oc; IOO, 6oc.

MissionaRy (Per.)-Doz. 25c; Ioo,6oc. ThIRD Class (Per.)-Doz. 25c; IOO, $60 c$.

Chas. Newman (Per.)-Doz. 25c; IOO, 6oc.

IMPROVED BUBACH (Imp.) -Do7. 25c; I00, 75 ; 1000, $\$ 6$. 


\section{Raspberries}

All kinds of raspberries have paid exceedingly well during the past few years. Several years ago there was a depression in the business, due to over production. Prices ruled low and raspberries proved far less profitable than strawberries. We have sold thousands of quarts at 5 and 6 cents per quart. Now the ruling wholesale price is ro cents and better, for black and purple berries; and I5 cents and better for pure red berries. The black and purple berries retail in the cities at I4 to 25 cents, and reds at from I8 to 30 cents per quart. It will be seen that, taking into consideration the enhanced price and the fact that raspberries can be grown so much more easily than strawberries, in profits they prove a close second to strawberries. Blackcaps are especially in great demand in the cities, due to the fact that this fruit has become diseased in many sections and fails to produce good crops; and then, the black raspberry of today, as represented in our best varieties, is more meaty, less seedy and far superior to the blackcaps of several years ago. The demand for raspberry plants of all kinds is enormous at the present time and almost impossible to oupply.

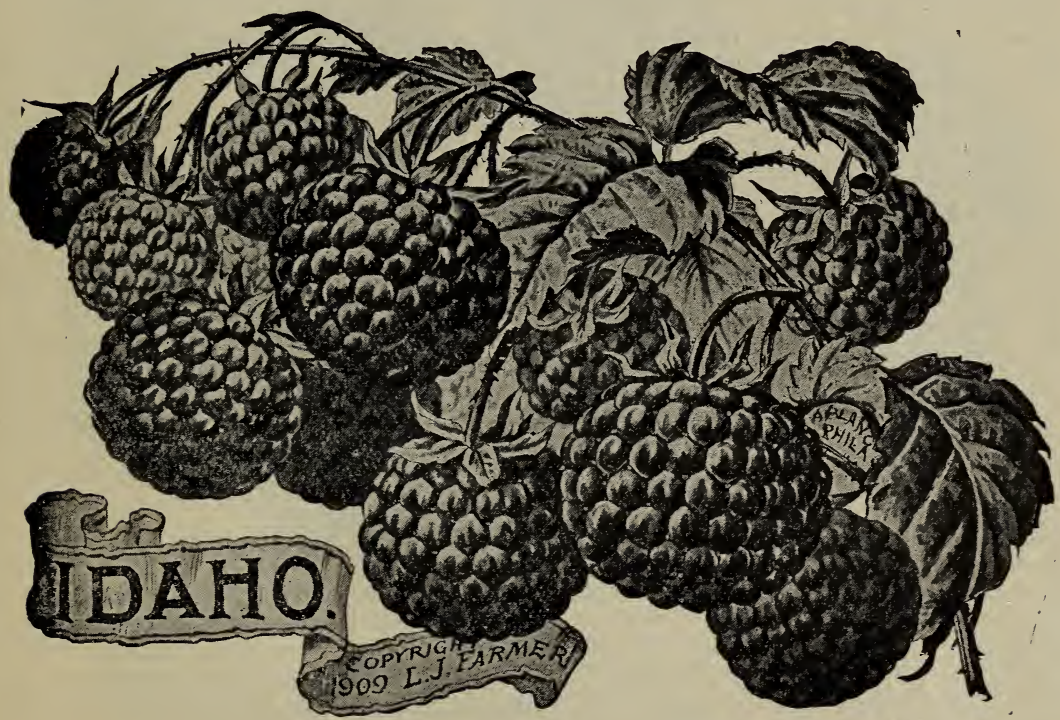

\section{CULTURAL DIRECTIONS}

There are three types of raspberries in common cultivation; the blacks, the reds and the purple varieties. The reds grow more upright than the others and can be planted much closer together on that account. The purple varieties are the strongest growers and also the most productive of all, but the color is unattractive and the customer must be educated to their use. When once known, they sell readily and are especially adapted for home use. The reds are of the very highest quality and most appreciated by epicures. If we could have just what we prefer, we would choose the reds for table use. the blacks for pies and the purple berries for canning. We believe in planting raspherry plants close in the row-say I to 2 feetas this induces many canes which grow small and withy and are not broken off by the winds as when set several feet apart, and only one or two canes allowed to the hill, which grows very large and are easily twisted off at the base by the winds. Red raspberries can be set in rows 5 or 6 feet apart; blacks from 6 to 7 feet apart and purple varieties from 6 to 8 feet apart. The plants should be set late in the fall or early in the spring before the main germ, which grows the canes, has started to grow much. We have also had wonderfully good success in allowing 
the young shoots to get from 6 to 18 inches high before taking up and transplanting. In fact, the best field of raspberries we ever had was planted with these green plants, in late May and early June. We set a patch, the past summer, in late June with wonderful results. It is always unwise to set raspberry plants that have the young germs sprouted so they just peep through the earth before they are taken up. These are very liable to get broken off and destroyed. In setting raspberry plants it is a good plan to provide for some loss, by trenching in a few extra plan: $s$ to fill out vacancies later on,during wet, lowery spells. In round numbers, it takes about 2000 raspberry plants to set an acre. They yield from 2000 to 5000 quarts to the acre, more or less. The plants must be kept free from weeds by hand hoeing and horse cultivation, the first year; afterwards most of the work can be done by cultivator and one-horse plow. We nip the canes when one foot high, the first year, and when 18 inches to $2 \mathrm{f}<$ et high, the second year, which causes the bush to branch and produce its fruit near the ground. In trimming, take off abous $1 / 3$ of the growth in early spring every year. In fertilizing, use commercial fertilizers, not too rich in nitrogen. Use a brand analyzing about two per cent nitrogen to Io per cent phos. acid and ro per cent potash. If 500 pounds of these goods are used on each acre per year, the field can be kept in profitable production for several years. Neglect the fertilizing and the first crop is the best and afterwards the plants rapidly deteriorate. In furnishing raspberry plants to our customers, we prefer to ship very early, as the green growing plants are more expensive to pa.k. We store many thousands in cuol cellars and hold back, to fill orders received after the first early orders are shipped.

\section{Black Varieties}

PLUM FARMER.-This grand black cap raspberry was found by us in a lot of black cap plants received from Ohio several years ago. We have fruited it and sold plants from it for nearly I5 years and in all this time, while we have tried numerous varieties, we never have seen anything that could near approach it in value. The plants are fine growers, being more free from diseases of black caps than other varieties; are clean silvery bluish in appearance when ripened in the fall and when loaded in fruit are a sight to behold. It ripens very early and most of the fruit is produced in one week. It will outyield any black cap we luave ever seen. The fruit is very large, thick meat $d$ and very firm, making a good berry to evaporate or ship to distant markets. The past season, one grower shipped yo crates to New York City and they all sold for 18 cents per quart, except three crates which brought 20 cents per quart. There is more money made in this variety in this locality than in any other variety of fruit I know of, considering the labor and expense. It is a good berry to use to pay off mortgages and long standing debts. It is being planted in all great raspberry sections from the Atlantic to the Pacific and is meeting with universal favor. We have received testimonials praising it from hundreds of leading fruit growers in all parts of the United States. It was named in our honor by an old friend and former employe. It advertises us and our business every year more than any other factor. I unhesitatingly re- commend it to all planters. For the past three years we have been unable to supply the demand for plants, bnt this year we offer nearly half a million of them, and while the demand is very large, we believe we will be able to supply everybody with plants. Our plants this year are the finest we liave ever sold. No. I plants, doz, 5oc; 100, \$I.50; 1000, \$12.50. Extra selects, from first putting down, doz, 75c; IOo, \$2; IOOO, \$I5.

Black Diamond.-Doz, 5oc; Ioo, \$2; IOOO, \$I5.

CUMBerland. - Doz, 5oc; IOO, \$2; IOOO, $\$ 15$.

GREGG.-Doz, 50c; Ico, \$2; IOOO, \$15.

NEW STONE FORT.-Doz, 5OC; IOO, $\$ 2$; IOOO, $\$ 15$.

NEW AMERICAN.-Doz, $\$ \mathrm{I} ;$ IOO, $\$ 5$.

EUREKA.-DOZ, 5OC: IOO, \$2.

ConRath.-Doz, 50c; IOO, $\$ 2$.

KaNSAS.-Doz, 50c; IOO, \$2; I000, \$15.

\section{Dark Red or Purple Varieties}

ROYAL, PURPLE.-This variety was oriignated in Indiana by L. H. Girton, of Bristol County, an old nurseryman with years of experience. He says that he has never seen anything that could approach it in value. The original bush has stood for 12 years in the same place and has borne a good crop every year, although at times it has been choked with a stiff blue grass sod, and the mercury has sometimes gone to 35 degrees below zero. We have the plants growing on our place and are wonderfully 
pleased with them and the fruit they|them at the rate of 5000 qts. to the acre bear. The Royal Purple is a strong, at one picking. It is tine for home use sturdy growing bush, with smooth canes and where large quantities of raspberries which in color are a deep glossy red, and are wanted at moderate price-they can very beautiful in appearance. The canes be grown so cheaply. The fruit is very are entirely free from disease and more large, meaty and firm, but picks rather hardy than other purple raspberries. As hard unless pretty ripe, and sometimes the canes are thornless, except a few crumbles some in picking. Its dull color near the base of the bush, women can go is soon overlooked in market when the through these bushes and pick the fruit housewife learns that the grower can without tearing and soiling good clothes. well afford to sell them for a few pennies The fruit is very large, firm and meaty less than real red raspberries. Like and can be picked easily without crumb- Early Ozark and Plum Farmer, Columling. It is very firm and can be handled bian is one of the great money makers. in quart baskets. Mr. Girton uses quarts Tips, doz, 50c; I00, थI.50; I000, \$12.

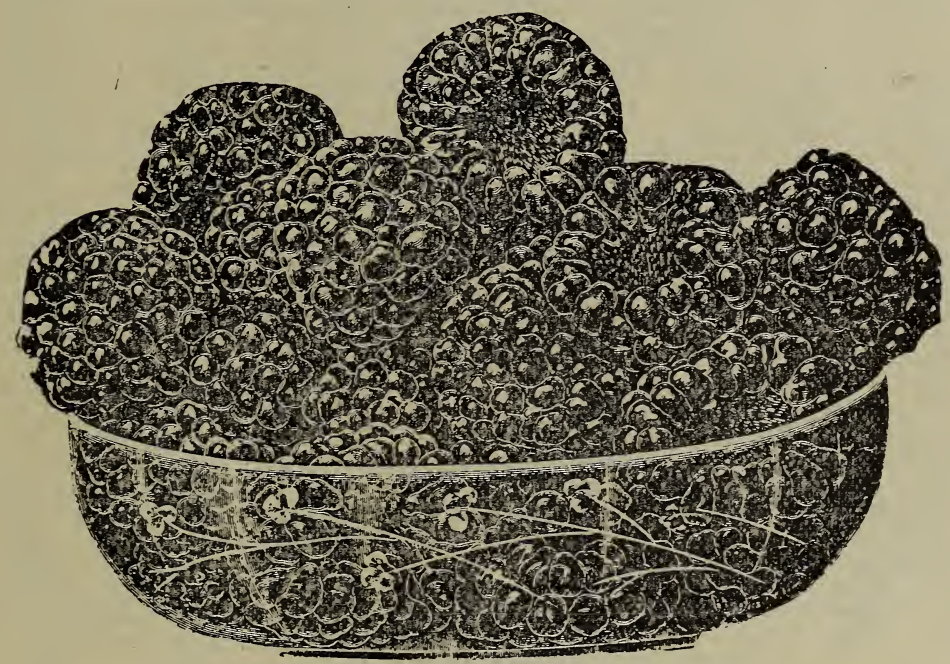

A DISH OF PLUM FARMER BLACK RASPBERRIES

entirely and draws his berries from 9 to 25 miles in order to reach his different markets. We offered a few plants last spring, at $\$ 5$ each. We now have a fair supply of plants and have reduced the price. Now is the time to invest in this grand berry. A few plants purchased now will increase to many in a few years. Price, I yr. transplants, \$I each; SIo per doz. Tip plants, 2 for $\$ \mathrm{I} ;$ doz, $\$ 5$; Ioo, $\$ 35$.

Columbian. - This variety is the standard among purple raspberries. It is a strong, healthy grower, sometimes making canes $I \frac{1}{4}$ inches in diameter The canes are yellow in color and pretty thorny. It is not entirely hardy, but in case the canes are frozen back, new canes will start from the roots and bear a crop of fruit the same season. I have picked $\$$ I5.
SCHAFFER'S COLOSSAL.-This was the first great purple raspberry. The canes are dark purple while those of the $\mathrm{Co}^{-}$ lumbian are yellow. It is not quite so rank a grower as the Columbian but is enormously prcductive and picks easily. The fruit is brighter in color and when picked before fully ripe, not much darker than red ras, berries. It is not quite so good a shipper as Columbian, but is fine for home use and near market. Some people prefer it to Columbian. Doz, $50 \mathrm{Oc}$; IOO, \$I.50; IOOO, \$I 2.

HAYMAKER.-Doz, 5Oc; IOO, \$2; IOOU, $\$ 15$.

CARDINAL.-Doz, 50c: Ioo, \$2; 1000, 


\section{Red Varieties}

IDAHo.-This is the most valuable red grower than Idaho and the varieties are raspberry that has ever fruited at Maple- entirely distinct. The supply of plants wood Fruit Farm. We purchased the is still limited. Price of Idaho, 5oc each; entire control of the plants from a fruit doz, $\$ 4 ;$ Ioo, $\$ 25$.

grower in Wisconsin, whose brother, a CUTHBERT.-This is the most popular conmercial traveler, discovered the of the well tested varieties. It is a plant growing in a garden in the state of rank, vigorous grower, making many ldaho. It was introduced by us two years plants which will soon encumber the ago, at $\$ 2$ per plant and we don't believe ground and become a nuisance unless any person who bought a plant then will kept cut back with hoe and cultivator. ever regret it. The plants are not rank The proper way to grow Cuthberts is to growers, but they are strong and sturdy keep them strictly in hills or very narand will assert themselves, no matter row rows, then the yield will be immense what the surroundings. It has a tend- and the berries large and fine. It ripens ency to grow stocky rather than tall, and midseason and continues to very late, we never have seen canes over $3 \frac{1}{2}$ feet selling for the best prices in market, high. It tends to branch like a tree The quality is superb. I pity the person without pruning, and this we think a who cannot enjoy a Cuthbert raspberry very valuable characteristic. The plants shortcake or the sauce when canned. are the hardiest of any raspberry we The demand for these plants is enorhave ever fruited. It has withstood over mous. Doz, $400 ;$ Ioo, $\$ 1.25 ;$ Iooo, $\$$ Io.

30 degrees below zero without injury and we believe it will stand 40 degrees below or even lower. The fruit is very large, sometimes attaining a size of $\mathrm{I} I / 4$ inches in diameter, and is very beautiful; of a deep rich red. In form it is flattened like black caps, rather than elongated, like most Ired raspberries. It has an agreeable, spicy flavor, all its own, and will be relished by all true epicures and those who do not like some well known kinds of red raspberries. It does not incumber the ground with canes like most red raspberries. It begins to ripen very early and continues very late, having the longest season of any red raspberry we know. We fruited 7 long rows of them the past summer and they were a sight. The fruit sold for more than other kinds and attracted the leading attention in market. We fruited the Eaton beside it this year, and the Idaho was fully four times as productive, larger and better every way. The Eaton is a ranker EAToN.-Doz, 50c; 100, \$3; 1000, \$20.

\section{Blackberries}

The blackberry is an exceedingly profitable fruit crop to grow, provided a satisfactory market can be obtained for them. The competition of wild ones has been a serious menace in many sections in years gone by, but this state of affairs is rapidly giving way to better conditions. The old slashes and wild places that used to grow up to blackberry plants after the timber was cut off, are now being rapidly reclaimed; and there is a limit to the production of wild blackberries. The cultivated crop will be more and more important and remunerative from year to year. It takes from Ioo to 200 plants, made up of several varieties to supply the family in. fresh fruit from day to day and enough to can; and it is better to have a supply in one's own garden, than to spend so much time in roaming the fields for wild ones.

\section{CULTURAL DIRECTIONS}

Blackberries require about the same treatment as raspberries, but should have a little more room. They do best on well drained land that does not hold water long after a rain. The rows must be marked 7 or 8 feet apart and the plants set 
from I to 3 feet apart in the rows. It is a good plan to plow deep furrows and set the plants in the bottom on the loose fine earth, filling in about them slightly when first set. As the plants grow, the furrows can be gradually filled until level full.

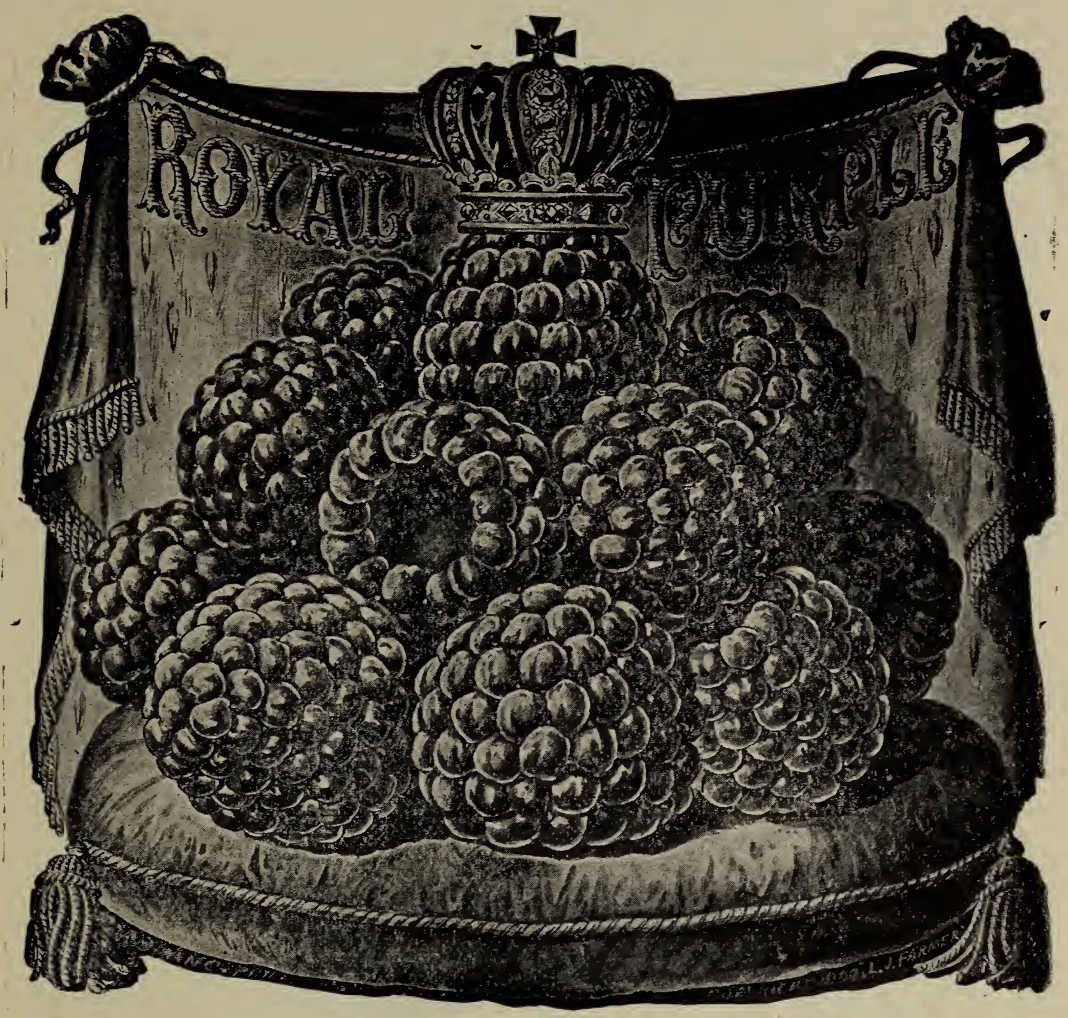

Cultivate the middles and hoe about the plants the first year sufficiently to keep weeds down and the plants growing. Treat all canes that come up between the rows as weeds, cut them off. Don't run the cultivator too deep, as every broken root sends up a sucker which will interfere with cultivation. Nip the canes back like raspberries to make the bush grow stocky and self supporting. When the canes finally crowd the paths, you can cut them off with bush hook or scythe to keep within bounds. Mulch under bushes where cultivator does not reach, and keep middles well cultivated from year to year.

\section{Varieties}

THE WATT BLACKBERRY.-Mr, Craw- $\mid$ Watt to be the most desirable of all, ford says: "This is a chance seedling when every point was considered. Hardithat came up in an orchard near Law- ness is an indispensible characteristic rence, Kansas, some ten years ago. After for this climate. The Watt is hardy as hearing very favorable reports of it from far as tested. It is a good grower, fully neighbors of the finder, we obtained it equal to any we have on our place. It is on trial some years ago. Last season we a good bearer, and ripens its berries over had it in full bearing alongside of the a long period from medium early until Eldorado. Blowers and Ward. After very late. The ftuit is large, roundish watching the behavior of all the varieties and glossy black. In quality it is one of to the end of the season, we found the the best.,' Doz, $\$ \mathrm{r} ;$ Ioo, $\$ 5$. 
SNYDER - This is the most reliable berries are large, long in shape, and are and popular variety for cold climates. sweet, like real wild long blackberries, The plants are stout, rugged growers, but are of better character. Doz, 5oc; upright in habit and produces immense IOO, \$2; IOOO, \$I5.

crops of fruit. It will withstand the most cold of any variety we grow, except possibly Ancient Briton. The berries are round in shape and of fine flavor when ripe; not real sweet but of good character. They are medium to large in size, depending upon the care they get. Its season is early and it lasts a long time. The canes are reddish in appearance. Doz, 50c; IOO, \$I.50; IO0O, \$1O.

ELDORADO.-A sweet blackberry very similar to Taylor in everthing except color of canes, which are red like Snyder. It is hardy and productive. Doz, 50c; IOO, $\$ 2 ; 1000, \$ 15$.

WARD.-A very popular new variety grown largely at its home in New Jersey. It is seedling of the famous Kittatinny, surpassing that famous variety in its

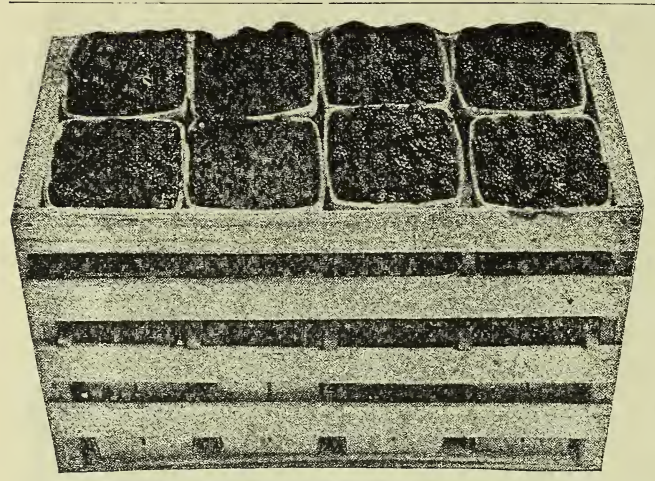

\section{TESTIMONIALS}

Jenera,Hancock Co.,O.,Dec.ro,'og My order No. I5374 of berry plants, received from you last spring are the nicest and best looking and giowing plants I ever received. PETER RAUCH.

Lawley, Ala., April 22, 'og.

I received the strawberryplants yesterday and set them out. They seemed to be as fresil as though they had just come out of the ground. S. F. LAWRENCE.

Madisonville, O., April 2I, 'og. My order received in prime condition. Finest plants I ever saw, and the currant bushes are thoroughbreds sure enough. Everything doing fine.

S. C. HIGBEE.

\section{A CRATE OF BLOWERS' BLACKBERRIES}

BLOWERS.-This is the most remarkable blackberry of the age. A woman discovered it growing wild and it has been propogated by its disseminator until he now has over 9 acres in fruiting. It is extremely vigorous and productive and quite hardy, but not so hardy as Snyder. It has been grown I4 feet in height and single bushes have produced as high as 2694 berries. The original $1 / 3$ acre has borne in five years, the enormous crop of Io, 637 quarts. It has the longest fruiting season of any blackberry, lasting from July to October, producing the greatest crop in August and quanti.ies in September. It is very attractive for market on account of its large size and excellent appearance. In I907 Mr. Blowers :old his entire crop to the grocerymen for $\$ 4.80$ per bushel. One acre picked I Io bushels, or over $\$ 500$ to the acre. It sells for $2 \mathrm{c}$ per qt. above other blackberries. Strong plants, doz, 75 c; 100, \$3.00; 1000, $\$ 25$.

TAYLOR.-This variety is later than Snyder and almost as hardy. The canes are greenish yellow in appearance and produce immense crops of fruit. The

palmiest days. Doz, 50c; IOO, \$2.50; IOOO, \$2O.

ANCIENT BRITON.-This is counted as the hardiest blackberry, producing a large crop of berries when others freeze to the snow line. The berries are large, long and sweet. Doz, 50; IOO, \$2.50; IOOO, \$2O.

ERIE.-This is the largest blackberry we have ever grown. The canes are stout, vigorous growers, branching naturally and produce immense crops. It is not quite hardy in extremely cold sections. Doz, 50c; Ioo, $\$ 2$; I000, \$15.

EARLY HARVEST. - This is a very early and productive variety, ripening a large crop of 1 ruit before Snyder and therefore very profitable. Doz, 50c; Ioo, \$I.50; IOOO, \$IO.

LUCRETIA DEWBERRY.-This trailing or running blackberry is a very interesting and profitable berry to grow. They must be trained much the same as grapes, either run over trellises, tied to stakes or kept in closely pruned hills. When cared for intelligently, they produce immense crops of fruit of the larg- 
est size-larger than ordinary varieties/color and large size, brings the very of blackberries. It ripens after straw- highest prices in market. Doz., 50c; 100, berries and on account of its season, its \$I.50; I000, \$10.

\section{Currants}

This fruit requires moist rich soil in order to do its best. The plants should be set in rows about 5 or 6 feet apart, with plants from 3 to 4 feet apart in the rows. Keep clean of weeds by horse cultivator and hand hoeing. Mulch with straw about the bushes during fruiting or sow buckwheat between the rows for this purpose sometime before the fruit begins to color. Fertilize every fall by putting a shovel of manure about each bush. "Trim out part of the old wood each year to prevent undue crowding of the bush. Keep sprayed with Bordeaux to prevent mildew. Sprinkle Paris green or helibore over the leaves to destroy the worms, in early spring and just before the fruit ripens. Gooseberries require the same treatment as currants. A doz $\leq n$ currant and a dozen gooseberry bushes will supply an ordinary family with plenty of fruit.

\section{Varieties}

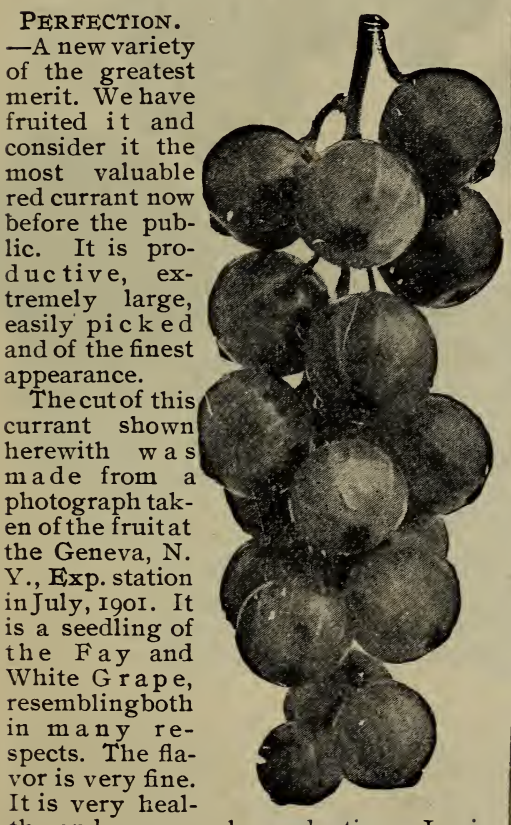

thy and enormously productive. In size it is as large or larger than Fay. It is the most popular new currant of the day and the sales of plants are enormous. It

won the $\$ 50$ Barry Medal offered by Western N. Y. Hort. Society; also the highest awards at Pan American Exposition and the Gold Medal at St.Louis World's Fair. Price, 20c each; doz, \$2; Ioo, \$I2.

FAy's PROLIFIC. - The most popular of all the older varieties of currants. It is early, large, of good color and very productive. It succeeds on lighter soils than other varieties. It is easily propogated from cuttings or layers. Ioc each; doz, \$I; IOO, \$5.

WILDER.-A large, flne flavored red currant of fine form and very productive. Highly endorsed by Mr. S. D. Willard and other good authorities. Ioc each; doz, \$I; IOO, \$5.

WHITE GRAPE.-A beautiful yellowish white currant; the finest flavored and best for table use of all currants; very large, sweet and delicious. Ioc each; doz, \$I; IOO, \$5.

Pomona,-A large, extremely productive red currant of good color and fine flavor. Ioc each; doz, $\$ \mathrm{I}$; Ioo, $\$ 5$,

RED CROSS.-In great demand because of its large size, beautiful color and productiveness. IOc each; doz, $\$ \mathrm{I} ;$ IOO, $\$ 5$.

\section{Gooseberries}

DownING.-This is the best known of all gooseberries. It is a medium sized fruit, pale green in color. The bush is a thrifty grower and enormously productive.
HoUGHTON.-A very hardy, vigorous growing bush, enormously productive of smooth, pale red berries of only small to medium size. It is of excellent quality. Josselyn. - An improved American sort, larger than Downing and same color 
asHoughton. Very productive and desirable.

INDUSTRY, PEARL.-Prices of above gooseberry plants, I5c each; doz, \$r.5o.
Chautaugua, Keepsake, Columbus. Triumph, INDUSTRy, Portage. - 20C each; doz, \$2.

CARRIE (new).--5oc each; doz, $\$ 5$.

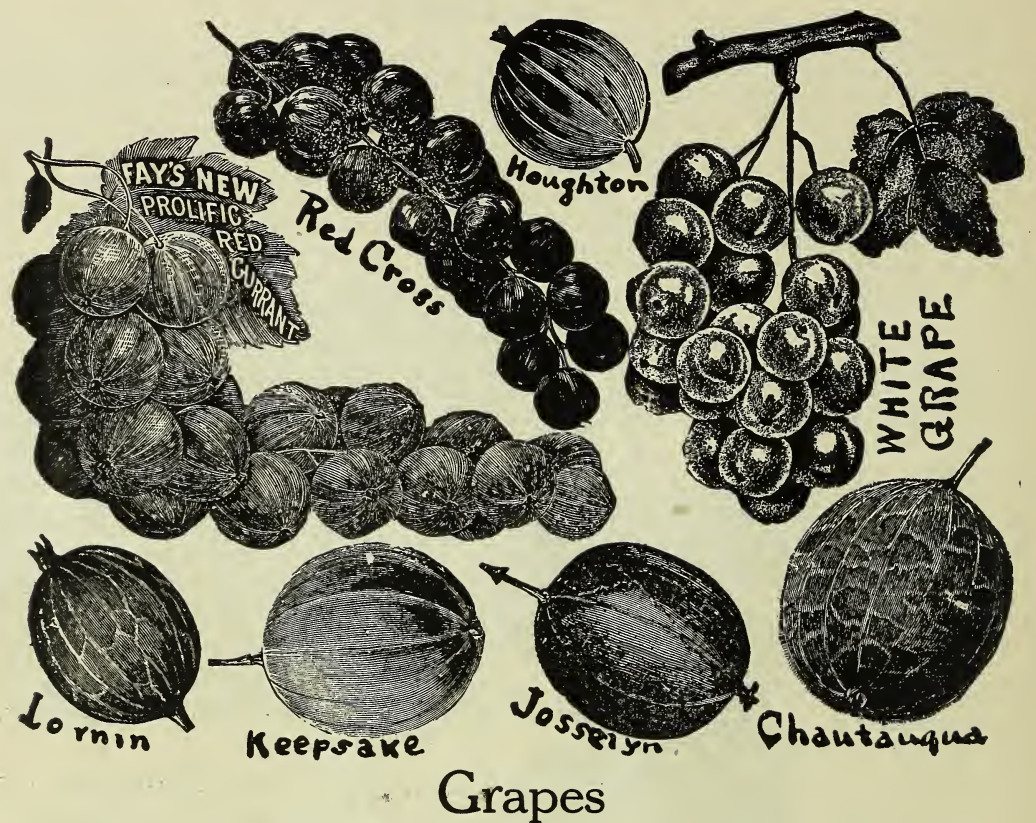

Grapes prefer sunny locations, so plant on the south side of buildings, fences and to cover unsightly objects. Every farmer should have a supply for home use. There is hardly a location but that will grow some of the varieties we list which are mainly adapted for the North. They seem to do best near buildings where the soil is loose, rich and mellow. Plant the vines from 6 to ro feet apart, spread out the roots and cover them with 6 inches of mellow soil. Keep clean and the vines well trimmed.

PRUNING.-Vines when set, should be cut back to within three or four buds from the root. In November or early in spring before sap starts, they should be pruned liberally. In pruning rather tender vines, leave more wood than is needed, as some may be killed, and finish pruning in spring, as soon as leaves are nearly developed, when the life of the vine may be seen. In summer allow a good growth beyond the fruit, and about mid-summer, pinch off the ends of the branches to check them, and cut out feeble laterals and branches on which there is no fruit, then there will be much foliage to absorb matter and prepare nutriment, and by checking the growth of the wood, it will be appropriated to perfect the fruit. Do not pick off the foliage. The leaves, not the fruit, should be exposed to the sun. We urge this point, as thousands mistake and grapes are generally mismanaged. The two great errors are in neglecting to cut off useless wood in fall and spring and of depriving the plants of necessary foliage by too close pruning in summer, so as to prevent much fruit from setting. If too much sets, thin it in season, that the juices of the vine may not be wasted on what must be removed.

Prices given are for two years vines. We can supply one year vines at twothirds the price given for two-year vines. 


\section{Varieties}

MCKINLEX.-A new early white grape best for both market and table use. raised from seed of cross between Niagara Ripens very early and fruit will hang on and Moore's Early, planted by F. L. vines 6 weeks without shelling. 2oc each; Young, of Niagara County, N. $v_{\text {., in }}$ doz. $\$ 2$.

r89r. The vine is vigorous. healthy, productive, foliage thick and leathery. It ripens 10 days before Niagara and is the comiug early white grape. The pulp has no acid and parts readily from the seeds. The bunches are compact, medium in size, uniform, skin thin, green at first and turning to yellow when fully ripe. It is a good shipper and keeper. It has hung on the vines 6 weeks after ripening and has no tendency to shell. 50c each; doz, $\$ 4$.

MCPIKE-Fruit of largest size, single berries often measuring $I \frac{1}{2}$ inches in diameter. Bunch compact, of good size, quality excellent, seeds few and small, pulp melting and parts from the seeds readily, vigorous grower, hardy. Color black like Worden and ripening with that variety. $25 \mathrm{c}$ each; doz. $\$ 2.50$.

Niagara-A very vigorous, strong grower, hardy in most sections. Leaves thick, leathery and dark glossy green. Buuches very large, uniform, compact. Berries large, skin thin but tough, quality good, very little pulp, melting, sweet to the center. Productive, good shipper. I5c each; doz. \$I.5O.

WORDEN.-Originated in Oswego Co., N. Y.. where it is the favorite grape for home use. Vines moderate growers but produce immense annual crops. Bunch large, compact, handsome. Berries large. Color black, ripening a week or Io days before Concord. Skin thin, flavor excellent. I5c each; doz. \$I 5o,

GREEN MOUnTAIN.-The earliest goud grae. Color yellowish green. Vine good.grnwer, healthy and productive.

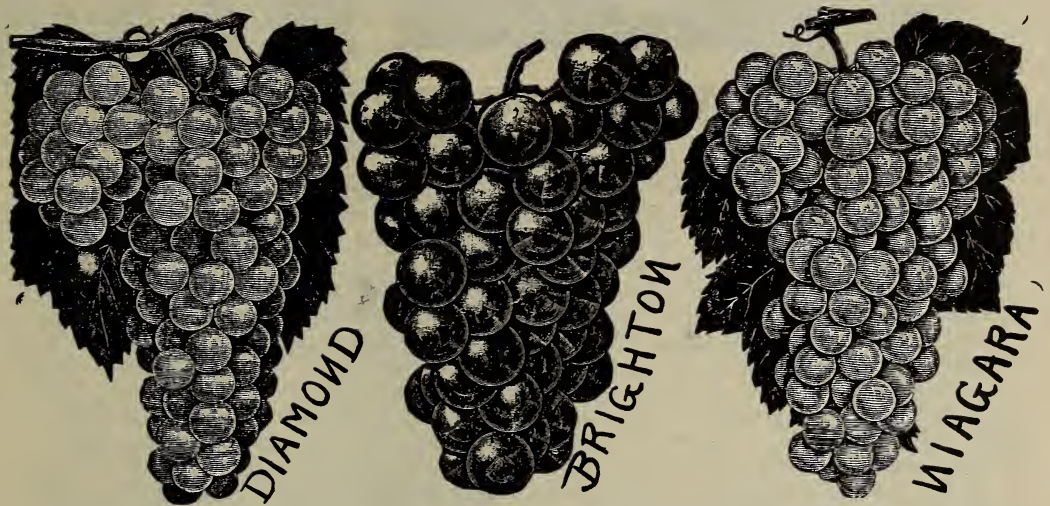

CAMPBELL'S EARLY-Originated by Berries medium in size. Quality good, the late Geo. W. Campbell, of Ohio, and flavor sweet, pure, delicious. Good the result of long continued experiments keeper. 25c each; doz. \$2.

to produce a variety superior to the Con- ConCoRD. - Vigorous, healthy, procord. Vines vigorous, healthy, hardy ductive. Berries black, sweet and good and productive. The cluster is large keeper. Succeeds everywhere. Ioc each; shouldered, compact, stem large, long; doz. \$I.

berry large, nearly round, black with Moore's Diamond, Moore's Early, profuse light blue bloom; skin thin with Brighton, Catawba, Agawan, Green's slight pulpiness, very tender and juicy, Early, Lindley, Delaware. I5c each; flavor sweet, rich; aroma delicate; quality doz. \$I.5O.

\section{Asparagus}

The culture of asparagus for market purposes is very profitable. It comes the first thing in spring when everybody is looking for some fresh vegetable and it is almost impossible to supply the demand. Asparagus pays fully as well as strawberries. If properly set and intelligently cared for afterwards, it may be kept in 
the same place for many years. There are patches in this locality that were planted years before I was born that are now bearing good crops every year. No farmer can afford to go without this vegetable; it is nature's remedy for toning up the blood and cleansing the kidneys after a long hard winter. We simply live on asparagus from the first warm spell in the spring until strawberries come. Mrs. Farmer cooks asparagus the same as green peas and in taste, it closely resembles
that vegetable.

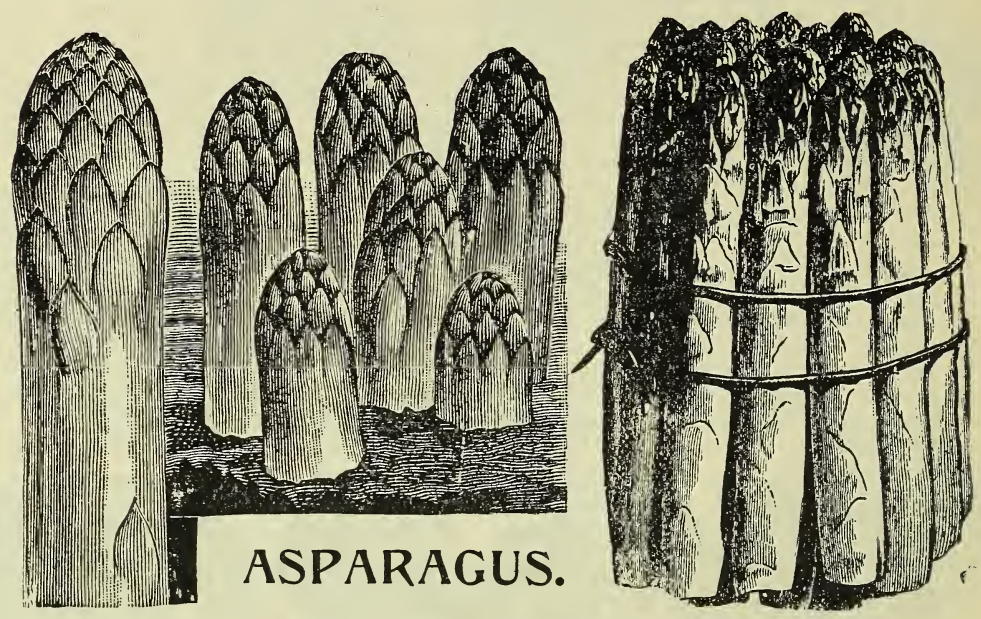

\section{How to Grow Asparagus}

You can make a lot of work of setting your asparagus bed or you can do the job comparatively easy. The results will be about the same. The old way of putting so much labor and expense into the preparation of the asparagus bed was all superfluous. The crop requires good rich soil, mellow and quite deep. It must be well drained and well elevated, and as far as possible removed from being subject to frost in early spring. When frost comes in early spring, it kills the tender growth of asparagus to the ground and new shoots must come up from the roots.

In preparing the land for asparagus, we plow deep, thoroughly refine the land with harrow or cultivator and then make deep furrows where the rows are to be, about 4 feet apart. If part of the soil rattles back into the furrow, we clean it out with shovel and drop the roots in the bottom, about I foot apart. If the rows are 4 feet apart and the plants I foot apart in the row, it will take ten thousand plants to the acre. After the plants are set, they should be covered with about two or three inches of soil, not deeper, allowing the shoots to come up through and get a foot or so in height before the furrow is filled in level with the surface of the ground. The soil may be drawn into the furrow at different times and the weeds kept down by this filling in. All thistles and perennial weeds must be kept pulled to prevent choking of the young plants. Horse cultivation must be kept up continuously as is necessary throughout the growing season. The bed need not be covered for winter. The growth of grass will die down in the fall with heavy'frost and can it be cut and removed. Manure from the stable can be spread in the fall or commercial fertilizers early in the spring and harrowed in to the soil before growth starts. The same culture must be kept up from year to year. After the first year, the rows can be salted to keep down the weeds and the cultivator run between the rows. Do not cut asparagus for market or table use until the asparagus bed has been set two years. Cutting off the green succulent shoots, tends to weaken the plant, so don't cut much till the bed becomes strong and well established. After once well established, if well cared for and annually enriched with plenty of fertilizer, it may be cut as fast as it gets large enough until well into the summer, after which it must be allowed to grow up and mature. Remember that asparagus is just the opposite of meadow grass, the oftener you cut it, the more it weakens the roots and plants. 
Prices OF PlANTS.-We supply Conover's Colossal, Palmetto, Bárr's Mammoth, Columbian Mammoth White, Donald's Elmira and Giant Argenteil at 25c per doz; \$I per IOo; \$5 per Iooo for 2 year old roots.

\section{Rhubarb or Pieplant}

This is one of the first vegetables to start in the spring and furnishes material for pies and sauce before anything else in the fruit line is available. Pieplant is not only palatable but is healthful, tending to clear the blood of impurities in early spring when most needed. The roots are very easy to make thrive if given rick soil and kept clean of weeds and grass. Stable manure applied each fall will greatls facilitate growth. After the roots have been set five or six years, they should be taken up, divided and re-set. If left too long in one place, the tendency is to grow a large number of weak, spindling stalks. If barrels or boxes are placed over the plants in early spring to exclude the light and keep away the frosis and cold winds, the stalks will make a large growth much earlier than otherwise and the growth will be all stalk, with very little leaf. If the p'ants are taken up late in the autumn, allowed to freeze and then set in the cellar with earth around the roots, the stalks will grow all winter. The warmer the cellar the more growth.

LINNAEUS.-Early, tender, delicious, finest flavor.

VICroRIA. - Larger, later; grows to mammoth size. Ioc each; doz, 75c; IoO, \$5.

\section{Out Door Roses}

Roses require rich soil with plenty of vegetable fibre in it, in order to do their best. They must be partially protected anywhere in New York State and similar latitudes. Barn manures are best for roses and it must be put about them in the

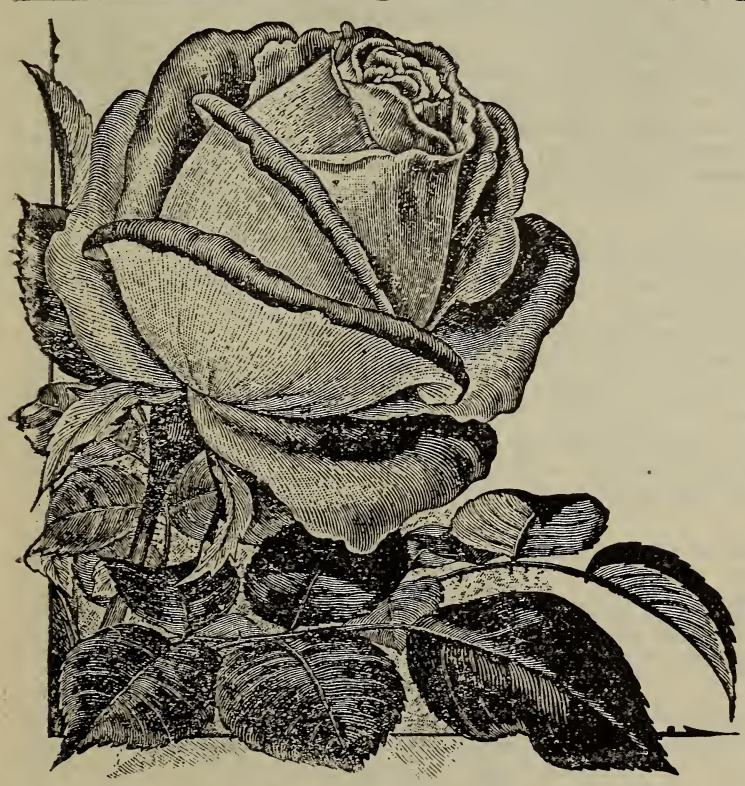

St. Joseph, Mo., Apr.20; $x$. We received the plants on the Igth in the finest condition. You are ahead of all the rest of them for fine roots and most excel. lent packing.

BERT WEBB.

Honolulu. Hawaii,

The PlumFarmer plants are doing fine. I shall or. der some more when I am able to get the ground prepared.

JOSEPH MCMASTER.

Montrose, Colo., Aprii is, 'og.

I received the raspberry, gooseberry and currant plants all in excellent hape a few days ago.

H. W. CHRISTOPHER.

Canandaigua, N. Y. April 24, I909.

Received your straw. berry book,catalogue and also plants some time ago. Ain well pleased. THOS. H. O'BRIEN.

Milwaukie, Oregon. Nov, 25 , 'og.

I received berry plants and they got here in fine shape. The plants are number one, the best I ev. er got from any nurseryman. JOHN DOLLANSKY.

t. I when thev are dormant Only slight coverings are necessary, sich as boxes, 1 .rrels and the like; stood over the bushes to keep away the extreme cold and snow from breaking them down. All broken and diseased wood must be cut away each spring and the new branches cut back about $1 / 3$ in length. Our rose bushes are not 
to be compared with the cheap trash offered by department stores and at the price we ask for them-25c each or $\$ 2.50$ per dozen-are real bargains. Most every bush will bloom freely the first year set out. We offer a smaller grade of plants at Ioc each; \$I per dozen. Add 5c for each rose plant, if by mail.

\section{Varieties}

CRIMSON R.AMBLER.-This is undoubtedly the most popular of all roses. It is hardy, wonderfully free flowering, rich glowing crimson, intensely bright and vivid in color. The plant is a strong, rampant grower, making sloots Io to I2 feet long after the first year. The flowers are produced in great trusses, pyramidal in shape, often twenty-five to thirty in a cluster, fairly covering the plant from the ground to the top with a mass of bright glowing crimson, the most wonderful rose introduced in the past twenty-five years. $25 \mathrm{c}$ each.

BABY RAMBLER. - This is the new dwarf crimson rambler. The bush is dwarf and produces flowers the size, shape and color of Crimson Rambler. It blooms from spring until winter in the open ground and all the time if planted indoors. The plants are entirely hardy and healthy with us. It is a fine rose for indoors and for bedding and massing in private grounds and parks, cemeteries, etc. Everybody should try this rose. We have Ioo plants three years old as large as ordinary rose bushes, which we offer at $50 \mathrm{c}$ each; smaller plants, $25 \mathrm{c}$ each.

DOROTHY PERKINS.-This is a wonderful success with us, producing a great crop of roses when others fail. The flowers are shell pink in color and produced in great clusters like the Crimson Rambler. The bush is a rambler of the same strong growing habits as Crimson Rambler and even hardier. 25c each.

YELLOW RAMBLER.-Of the same general character as Crimson Rambler except color, which is a clear, decided yellow. 25c.

WHITE RAMBLER.-Like all ramblers except pure white color. 25c.

ALFRED CoLCOMB.-Brilliant carmine crimson; very large, full, fine globular, form. Extremely fragrant; fine sort, $25 \mathrm{c}$ each.

AMERICAN BEAUTY.-Large, globular, pink, shaded with carmine; delicious odor. $50 \mathrm{oc}$ each.

ANNA DE DIESBACH.-Carmine, a beautiful shade; very hardy, large and double, very fragrant. A fine garden sort, $25 \mathrm{c}$

CAPRICE.-Large, pink, striped and dashed with white and carmine; vigorous and free bloomer. $25 \mathrm{c}$ each.
COQUETTE DES ALPES.-White, center slightly shaded with carmine; flowers finely formed, vigorous grower, profuse bloomer. $\mathrm{z} 5 \mathrm{c}$ each.

CoQ. DES BLANCHES. - White sometimes tinted with blush, medium size; very full,somewhat flattened; very pretty.

EARL, OF DUFFERIN.-Rich, brilliant, velvety crimson, shaded with dark maroon; large, full, finely formed; delightful fragrance; a vigorous grower. One of the finest dark roses. $25 \mathrm{c}$ each.

FISHER HoLMES.-Deep glowing crimson; large, moderately full and of fine imbricated form. A superb rose. 25c each.

GENERAL JACQUEMINOT. - Brilliant crimson scarlet; very showy; free bloomer, fragrant, hardy, strong grower; very prolific. $25 \mathrm{c}$ each.

GenNERAL WASHINGTON. - Brilliant, rosy carmine, large double fine form and effective; free bloomer. $25 \mathrm{c}$ each.

GLORIE DE MARGOTTEN.-Rich, dazzling crimson. Makes beautiful long pointed buds, flowers when open, large, of good shape. A vigorous grower and remarkably free flowering. $25 \mathrm{c}$ each.

JOHN HOPPER.-Deep rose, with crimson center; large fine form, profuse bloomer. 25c each.

LA FRANCE.-Silvery pink, very large fine form, free bloomer, distinct and beautiful. A superb rose. 25c each.

MADAMME GABRIEL, LUIZET.-Very distinct pink, large cup shaped, fragrant. It has no rival as an exhibition rose. $25 \mathrm{C}$ each.

MADAMME Plantier.-Pure white, above medium size, produced in great abundance early in season. One of the best hardy white roses, sometimes called the cemetery rose. $25 \mathrm{c}$ each.

MAGNa CHARTA.-Bright pink, suffused with carmine; very large, full, of good form. Habit erect, magnificent foliage. Flowers produced in more than usual abundance. 25c each.

MARSHALI, P. WILDER.-(See illustration.) Cherry carmine, large size, good form, very fragrant, perpetual bloomer, vigorous grower, very valuable. $25 \mathrm{C}$ each. 
MARgareT Dickson. - Magnificent|bulbs, 6oc per doz.; \$2 per Ioo; price form, white with large pale flesh center. Petals very large, shell shaped and of great substance. Foliage very large, dark green. Fragrant. A fine variety. 25c each.

MRS. JOHN LAING.-Very free flowering, commencing to bloom early in the season, and continuing until autumn. Color a soft delicate pink, with a satin tinge; very fragrant. $25 \mathrm{c}$ each.

Paul, Neyron.-Deep red rose; splendid foliage and habit, with larger flowers than any other variety, free bloomer. $25 \mathrm{c}$ each.

PERSIAN YeLLOW.-Deep bright yellow, small but handsome; double. A very early bloomer, the finest hardy yellow rose. $50 \mathrm{oceach}$.

PRINCE CAMILIE DE ROHAN.-Deep velvet crimson, moderately full. A splendid rose, one of the darkest. $25 \mathrm{C}$ each.

SALET (Moss) --Bright rosy red, a vigorous grower, abundant bloomer, seldom surpassed, pretty in bud. 25c each.

Crested Moss (Moss).-Clear rose, buds beautifully crested, singular and distinct. $25 \mathrm{c}$ each.

BLANCHE MOREAU (Moss).- Pure white, full perfect form, buds and flowers produced in clusters, furnished with deep green moss. 25c each.

\section{GLADIOLUS BULBS}

We offer $\mathrm{I}_{5}, 000$ fine gladiolus bulbs, all blooming size, at lowest prices.

\section{Varieties}

STANDARD MIXTURE.-All the choicest colors, mixed up in right proportions to suit the ladies. Price of largest sized

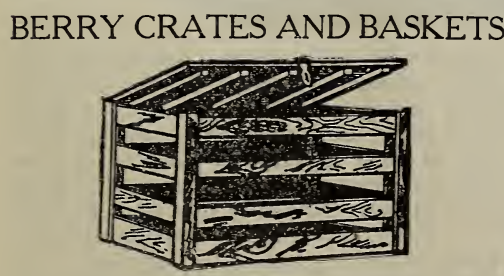

We can supply crates and baskets any time during the berry season, but prefer that orders be sent in some time before goods are manted. Price of crates, 32 or 36 quart size, 5oc each. This includes partitions. Price of baskets-Standard (flat) or Oswego (deep) $50 \mathrm{c}$ per Ioo, $\$ 4.00$ per Iooo. Special prices on larger lots. second size, $40 \mathrm{c}$ per doz.; \$I.50 per IoO. All bulbs are blooming size.

MADAMME LAMOINE.-One of the most beautiful gladiolus in existence. Sometimes called "Orchid" or "Butterfly" gladiolus. Price same as for Standard Mixture.

Write for prices on large lots of bulbs. We offer I5,000 bulbs

\section{DAHLIAS}

\section{Named Varieties}

A. D. Lavonia (pink), Maid of Kent (red) John Walker (white), Storm King (small white), Pompon (white), Lyndhurst (deep red), also Standard Mixture of all kinds and colors. Price of named and mixed kinds, $5 \mathrm{c}$ per tuber; $50 \mathrm{c}$ per doz.; by express

\section{CLEMATIS}

BARON VEILIARD - F lowers very large; light rose, with lilac shading; distinct.

MAD. FD. ANDRE.-Large, deep, velvety crimson flowers; a fine bloomer. New; a great acquisition.

HENRYII.-Of robust habit and very fine bloomer. Flowers large, beautiful creamy white; consisting generally of from six to eight petals. One of the finest white varieties.

JACKMANNI.-This variety bears a profusion of large sized, intense violet purple flowers; five inches across; richly veined and shaded with reddish purple; rapid grower; early and abundant bloomer; perfectly hardy and adapted to all kinds of culture. Price of any of the above, $35 \mathrm{c}$ each or four for \$I.25.

\section{$\$ 25.00$ in Gold}

I will pay (\$25.00) twenty five dollars in gold coin to the person who will grow the largest single berry of the Norwood Strawberry. Plants must be purchased of us this spring (IgIO) and award will be made on fruit gathered in IgII, from these plants. L. J. FARMER.

\section{$\$ 25.00$ in Gold}




\section{The Hastings Potato}

When I sent out this new potato, "Warren Hastings," last spring, I did not then realize it was as good as it is. I believe now that it is the best potato in the world. A lady near us sowed some tomato seeds and this potato came up among the tomato plants and was planted and saved. It has now fruited about five years and every year becomes more popular with those who plant it. It will yield fully double Carman, Rural New Yorker and others of the same type. The vines are the strongest growers we have ever seen, literally cover the ground and are almost immune to the attacks of bugs and blight. The tubers are same shape generally as Carman, are smooth, pretty in appearance, very solid and heavy. It cooks very floury and is the finest grained and best tasting potato I have ever eaten. I plowed in $1 / 4$ acre of them, dropping the potatoes $I$ font apart and in every third furrow. They were too thickly planted for the variety and while never touched with a hoe, merely $\mathrm{h}$ irrowed and cultivated, we harvested 75 bushels from the little plot. I think the best way to plant them is 3 feet apart each way and make a nice large

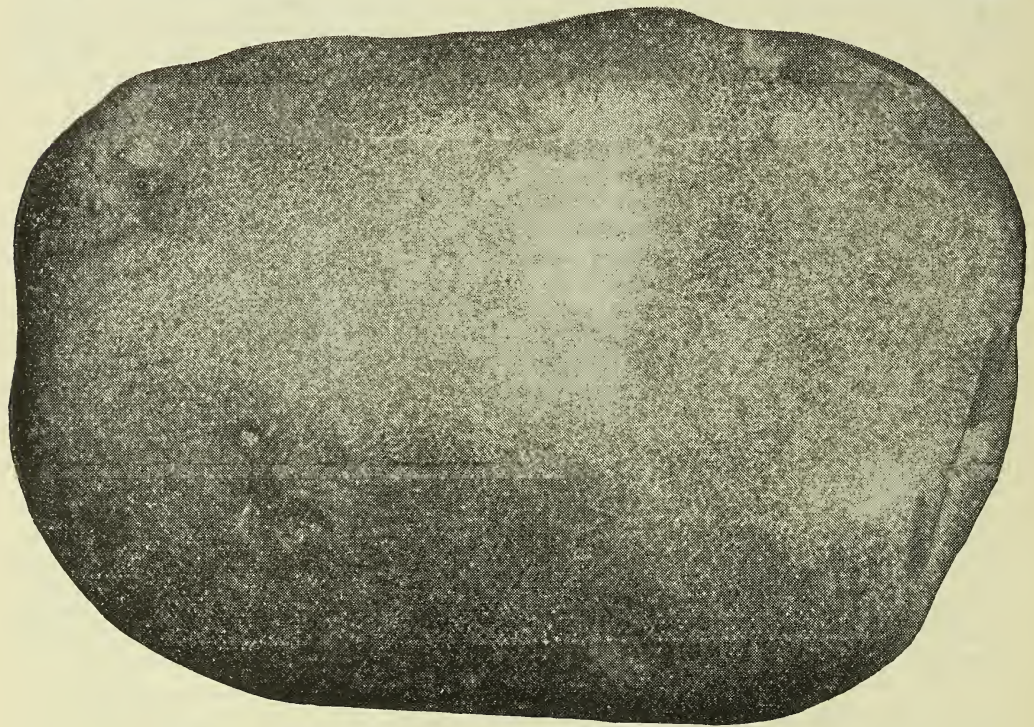

hill, and I believe in a good season that these hills will produce an average of a peck to the hill. I gave my cousin, Mr. Ralph 'armer, of Mexico, N. Y., the tuber used to make the illustration used in this and last year's catalogue. It weighed over one pound. He made I4 hills of the one tuber and raised 83 pounds of potatoes from the same. I never before heard of such a yield. I wish to impress upou my friends the fact that not only is this the most vigorous of growers, being practically immune to the attacks of disease and bugs. Not only is it an enormous yielder, but it is of the very finest quality. It is good to eat as soon as dug like early varieties, and unlike Cameran and Rural New Yorker, although it is a late potato and a very late keeper. It wil? mature a crop when planted quite late, but for the largest yields and best results we would plant it early. It will grow all summer and then the chances are that frost will kill the vines in the fall before they die naturally. Here is the secret of its quality and great yields. Price I tuber (about I lb) , 25c; peck, 75c; bu, $\$ 2$; Io bu, $\$ 15$. We have Iooo bushels to sell. Lord McCaulay said: "I consider Warren Hastings the greatest man England ever produced." I certainly consider the Hastings potato the greatest potato America has ever produced. 


\section{The Oswego Apple}

This apple was discovered by Daniel D. Tryon, of the Town of Sandy Creek, Oswego County, New York, several years ago. The young tree was found growing up through the branches of an old Northern Spy tree and was bearing fruit. Like other trees in the orchard, the old Spy tree had borne such heavy loads of fruit that most of its branches were split away from the main trunk of the tree and lay prostrate on the ground, yet were still bearing apples; and it was a pretty sight to see the young seedling tree bearing bright red apples and the Spy branches bearing fruit of the characteristic Spy coloring. The young tree is about four feet from the trunk of the parent tree and at present about 6 in. in diameter. It is impossible to tell whether the new variety is a seedling from apples from the Northern Spy tree or a sprout that came up from the roots of the old tree. The indications point

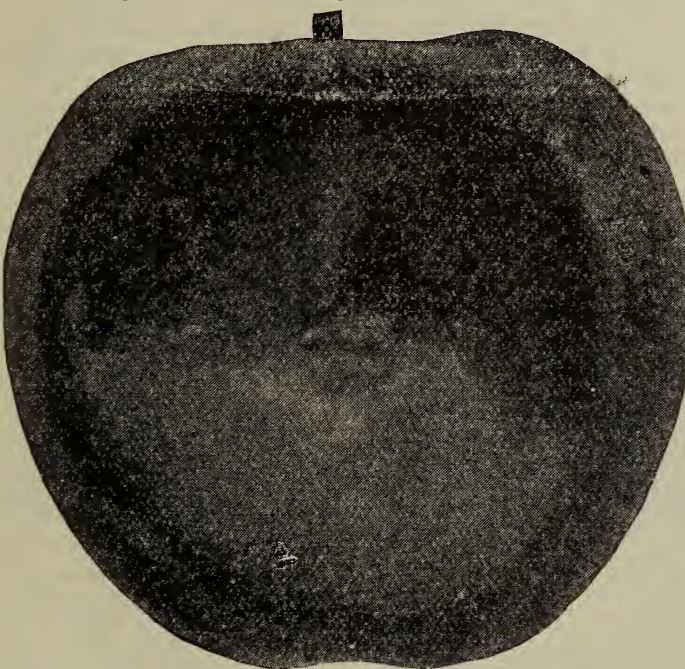
to the latter theory, as there is another sprout on the other side of the old tree of about the same size as the young Oswego tree, but this has never borne fruit. The color of the bark, growth and general appearance of the young Oswego tree are practically identical with the Northern Spy, and it certainly has Northern Spy blood in its make up. The tree begun to bear fruit five years ago and has borne a crop of apples for five succeeding seasons, never missing a crop, although this year, most of the apples are inferior because of neglect, like other apples in this locality that were not thinned and sprayed. The a phis" has caused all apples to be small and inferior. Last year the tree bore about three bushels of fruit and many were enabled to see the apples and judge of their value. We exhibited the fruit at the annual meeting of the New York State Fruit Growers' Association at Medina, N. Y., and also at the annual meeting of the Western New York Horticultural Society at Rochester, N. Y. The leading fruit growers, nurserymsn and horticulturists of the United States have seen and tasted the apples and are unqualifiedly enthusiastic about it. Such men as G. B. Brackett, Proffs. Beach, Hedrick, Craig, Stewart, Taylor, Slingerland. Whetzel and others. Such leading authorities as W. C. Barry, J. H. Hale, H. W. Collingwood, Chas. W. Garfield, T. B. Wilson, Clark Allis, Geo. T. Powell, Frank B. White, John Hall, J. S. Woodward, S. D. Willard, Albert Wood, D. D. Stone and others; such leading nurserymen as Chas. A. Green, H. S. Wiley, Nelson Bogue, C. M. Hooker, F. E. Rupert and others, have seen, tasted and admired it and to any or all of whom we refer anybody who is interested, for their private opinion.

The fruit averages the same size as the Northern Spy and has about the same general characteristics except color, which is a beautiful clear red with no stripes or splashes. Near the calyx end are small dots like those in the Spitzenburgh apple, and this characteristic, combined with the excellent quality, has lead the originator to think that the new variety is a cross of the Esopus Spitzenburgh and Northern Spy. The flesh is very fine grained, yellowish white, of a rich appearance, and has a flavor suggesting a cross of the Spy and Spitzenburgh. It has a crispy Spy taste, although not quite as juicy as the Spy. The apples are exceptionally fine in appearance and when placed among other varieties, attract the leading attention. The color is a beautiful deep red. While the season is about with 
the Spy, they are somewhat longer keepers. We never have shown them at the State Fair in Syracuse, as they do not color up fully quite so early as this is usually held.

At present the stock consists of the origiral tree and about rooo young trees budded and roots grafted. The originator is a practical fruit grower and nurseryman of years of experience and the stock will be multiplied fast as possible. We expect to place the first lot of trees on the market during the spring of I9II or I9I2. The price is to be fixed at $\$ \mathrm{I} .00$ per tree, regardless of quantity. Orders will be received at any time and filied in rotation as received. No order will be booked unless cash accompanies the order. We need the money to pay for propagating the trees. Reference, Pulaski National Bank, address The Farmer and Tryon Nursery Co., Pulaski, New York.

\section{Poultry Department}

Poultry and fruit make a strong combination, adapted to the man or woman who has a small piece of land. The droppings from poultry are very valuable to fertilize berries and the young chicks eat and destroy many insects that are harmful to fruits. We make a specialty of supplying eggs for hatching, but can also supply most varieties of fowls, except ducks and geese, at $\$ 2.50$ per single bird, male or female, and $\$ 6.00$ for trios. We keep ouly the White Wyandotte, ourselves. The other varieties of eggs are produced by different parties in this locality, who have made a specialty of their particular breed for many years. Pulaski is noted as a great poultry center and has many up-to-date poultry men. Every year these men go through their flocks in the fall and select the very best birds for breeding purposes, at the same time throwing out the culls. In this way the breeds are perfected and improved from year to year, New blood is introducod by the purchase of males from the leading breeders in all sections of the country. I believe that my practice of keeping but one breed on my farm and getting eggs from other breeders in this locality, who keep but one variety, is far better than to try to keep all kinds on one farm. This trying to keep birds of different breeds apart on one farm may be all right in theory, but in actual practice it is almost impossible to prevent them getting together accidentally at times. We believe there are ho better eggs produced for practical purposes than the ones that we have to sell. We exercise the greatest care to have all eggs pure and reliable. . We pack and deliver to express at prices attached.

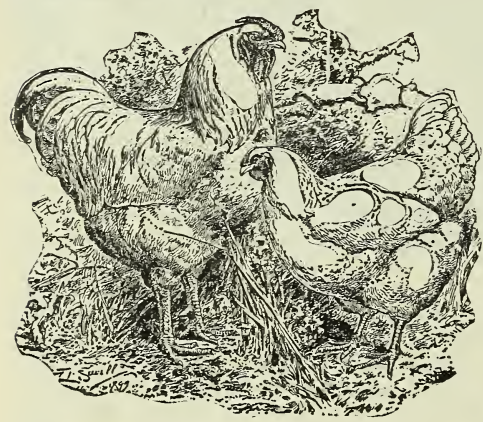

White WyandotTes (J ackson \& Dunston Strain).-This is the only variety that we keep on our own farm. They are a general purpose fowl, being as good layers as the Leghorns, and when dressed off, weigh nearly as much as the Plymouth Rocks. The eggs are of medium size, light brown and sometimes faintly speckled. The fowls are snow white with rose combs, yellow legs and mature early, being considered the very best variety for broilers. They lay throughout the greatest length of season of any variety we know, mature hens having the characteristic of laying late in the fall and early winter. Eggs, \$I per I3; \$I.75 per 26; \$5 per Ioo.

BARRED PLYMOUTH ROCKS (Hawkins, Felch, Thompson, Gardner and Dunning strains) - "The farmer's fowl" is of American origin. They have beautiful blue barred plumage, clean legs, and are good layers. They are an excellent table fowl being next in size to the Asiatics. The eggs are large and of a rich brown color. Eggs, \$I per I3; \$I.75 per 26; \$5 per IOo. BUFF Plymouth Rocks (Nuggetts, strain) - These all have the general characteristics of the Barred Rocks except color, which is a beautiful buff. They have yellow skin and lay an egg about the same color as the Barred. Considered by some to be superior to the Barred variety as layers, and easier to raise. Eggs, \$I per I $3 ;$ I.75 per 26; \$5 per Ioo. White PlyMOUTH Rocks (U. R. Fishel's strain) - Considered by many to be the best general purpose strain of fowls. The males weigh about $91 / 2 \mathrm{lbs}$. 
and the females $7 / 2 \mathrm{lbs}$. They are hardy and mature early; have yellow legs and skin and are excellent for market. 'Eggs $\$ 1.50$ per I3; $\$ 2.25$ per $26 ; \$ 6$ per 100 .

S. C. WHITE LEGHORNS (White \& Rice and Blancliard \& Wyckoff strains)-If large white eggs are the chief consideration, the White Leghorn is the variety to grow. They are very spry and active, good foragers and yet they bear confinement well. The eggs are exceedingly fertile and hatch well. The chicks are quite hardy and mature at an early age. The cocks weigh from $4 \frac{1}{2}$ to $51 \mathrm{bs}$; the hens from $3 \frac{1}{2}$ to 5 lbs. The pullets often lay when only four months old and are not inclined to sit. They must have warm quarters in winter if winter eggs are expected. This is possibly the most popular of the special egg producing variety and is more grown in this section than all other varieties combined. I can supply eggs in almost any quantity. Eggs, \$I per I3; \$I.75 per 26; \$5 per Ioo.

S. C. BUFF LEGHORNS-There is no more beautiful or useful fowl in existtence, today, than this variety of Leghorn. They are unsurpassed for laying qualities, having all the characteristics of the White Leghorn with added beauty. The strain I offer is one of the finest. Our eggs are produced by Mr. W. L. Bartlett, who has carefully bred the variety for years and much improved on the original strain. Eggs, $\$ 1.25$ per I3; $\$ 2$ per $26 ; \$ 6$ per Ioo.

S. C. White Leghorns (L. H. Perry strain).-Our supply of this variety of eggs will be produced, this year, by Mr. Perry himself, who has won first prizes at New York State Fair, also at Portland, Maine, and wherever his birds have been shown. This variety is rapidly supersedeing the single combed White Leghorn wherever it is known. There is no finer strain of eggs in the Unted States than we have to offer. Eggs, \$I.25 per I3; \$2 per 26; \$6 per Ioo.

S. C. BROWN LEGHORNS.-All the Leghorns have the same general characteristics. The Brown Leghorns have red wattle and comb, white ear lobes, are brown in color, except that the cock is black on breast, deep bay red on hackle. Each feather has a black stripe in center, back and saddle deep bay red, tail black. They have yellow skin and legs. Eggs, \$I per I3; \$I.75 per 26; \$5 per roo.

R. C. BROWN LEGHORNS (Kulp strain) -Are practically the same as S. C., except the comb. Eggs, \$1 per I3; \$1.75 per 26; $\$ 5$ per IOO.
S. C. Black MINORKas.-Of Spanish origin. Well adapted for generdl purpose fowls, laying large white eggs and producing a fowl which weighs for males 8 lbs. and females $6 r / 2$ lbs. The combs are prominent and very large; plumage black with a green metalic lustre. They are non-sitters, small eaters, splendid foragers and very profitable. Eggs, \$2 per I3, $\$ 3$ per 26 ; $\$ 6$ per Ioo.

LIGHT BRAHMAS. - This is one of the oldest breeds in existence, having been bred for centuries. They are very large, have a yellow skin and fatten nic ely when mature. They are gooll sitters and mothers. The eggs are quite large and brown in color. Mature cocks weigh, when in good condition, ro to I 2 lbs., and hen 8 to Io lbs. Eggs, \$I per I3; \$I.75 per 26; $\$ 5$ per Ioo.

ANCONAS, BLUE ANDALUSIANS-Eggs, $\$ 1.50$ per I3; $\$ 2.25$ per 26 .

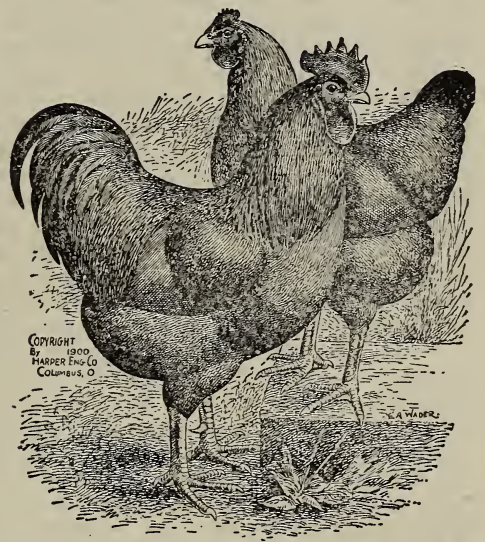

RHODE ISLAND REDS (Tompkins \& Cushman strain) -Rose Comb or Single Comb. This is a comparatively new fowl that is rapidly pushing its way to the front. It is considered the hardiest of all breeds, being less liable to colds and roup than any other breed. The males weigh from $7 \frac{1}{2}$ to $81 / 2$ lbs., and the females from 5 to $6 \frac{1}{2}$ lbs. They make rapid growth and are desirable at any age for the table. The pullets mature early and lay in the fall and early winter when eggs are high. They are very beautiful as well as useful and are considered an ideal all-around fowl. They are prolific layers of a beantiful large brown egg. I unhesitatingly recommend them to the general farmer who wants a hardy fowl. Our single comb Rhode Island Reds are especially fine, being carefully bred for years and our best eggs, 
this year, are fertilized with cockerels/seventy-five eggs in succession. Mature from sittings received from E. B. Tomp- ducks weigh from 7 to 9 pounds. Eggs, Jins, who has won first prize at all the shows. Eggs, \$I per I3; \$I.75 per 26; $\$ 5$ per roo. From best pens $\$ 2.00$ per I3, $\$ 3.50$ per $26, \$ 8.00$ per 100 .

PeKIN DUCKs - The Imperial Pekin Duck is the most popular of all ducks and is the most extensively raised. They are a large white duck, showing a rich, creamy white when mature and in good condition. They are very hardy, sometimes weighing 4 pounds and in full feather when only eight weeks old. They are very prolific layers, sometimes laying

\section{The Morris Wilson Farm For Sale}

This fine place is one of the leading dairy farms of Oswego County. It consists of 245 acres of strong undulating land located southwest of the village of Pulaski towards Oswego, 2 miles from Pulaski postoffice and I $3 / 4$ miles from Pulaski station. The soil varies from light to heavy clay loam and is especially adapted for pasturing, hay and grain raising. Forty cows were kept on this farm for many years and it is fully equal to carrying 50 cows if wanted. The land is rolling and most of it adapted for apples and other fruits. Apples do exceptionally fine. There is a wood lot amply large enough to supply the family with fuel and nccessary lumber. The buildings are in guod condition, especially the barn which was erected but a few years ago. There is a large silo aud a horse barn. Natural gas has been discoverred on the farm and one of the greatest wells ever put down in this locality was drilled but a few rods frum the barn, two years ago. Gas was discovered in immense quantities and was connected with the mains which run through Pulaski. It can be used for fuel and lighting on the farm if desired. The pasture is well watered by a creek which borders it. The house and other buildings are nicely protected from the cold winds by a strip of heavy timber on the North. This is a romantic location and will make an attractive home for any enterprising family.

The farm was known for years as the Peter Reyno!ds farm and was purchased by the late Morris Wilson in I867 for \$14,000 00. Mr. Wilson engaged in the dairy business and succeeded in paying for the farm from the receipts of the farm. Mr. Wilson died a few years ago, learing four children besides the widow. Mrs. L.J. Farmer is the eldest daughter. None of the cliildren are situated so they can run the farm, and so, finally it is offered for sale and at a bargain. It can be purchased with 25 cows now for $\$ 8.000 .00$. Tuis is at the rate of only $\$ 30$ per acre, and as a bargain, cannot be equalled in this locality.

Palaski is the center of the greatest dairying interest in New York State. The farmers have organized an incorporated company known as the Dairymen's Protective Association of Pulaski which owns and operates two plants and protects the interests of the dairymen in this locality. There are also located in Pula-ki a condensary and two other large plants for the making up of milk into various products. "The price receired for milk will average roc. or better per Ioo lbs, above other lacalities in New Lork State. There are several dairymen whuse cows will amerage nearly $\$ 100$ per head in gross sales of milk during the past year. One farm two milles from Pulaski has just sold for $\$ 100$ per acre. Now is the time to buy the Wilson farm. For any further information address $I_{1}$. J. Farmer, Pulaski, New York.

\section{The Early Michigan Potato}

We have had this grand early potato ever since it was first introduced. We have tried most all of the new and old ones and have never found anything quite equall to it in appearance, quality and productiveness for an early potato. It is an oblong potato of the Beauty of Hebron type; creamy white and of the very finest quality. I know of leading potato growers who plant it for main crop, claiming it as productive as mıst 1 ate varieties. It is only a few days later than Early Obio and very much more productive and attractive. We have a large fine stock. Single tuiber, I.5c; pk., 3.5c; ibu, \$1.25; 10 bu, \$10. 
If you are interested in growing things you need

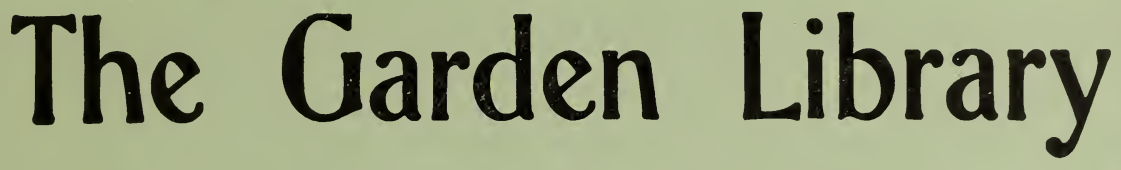

\section{NOW COMPLETE IN NINE VOLUMES}

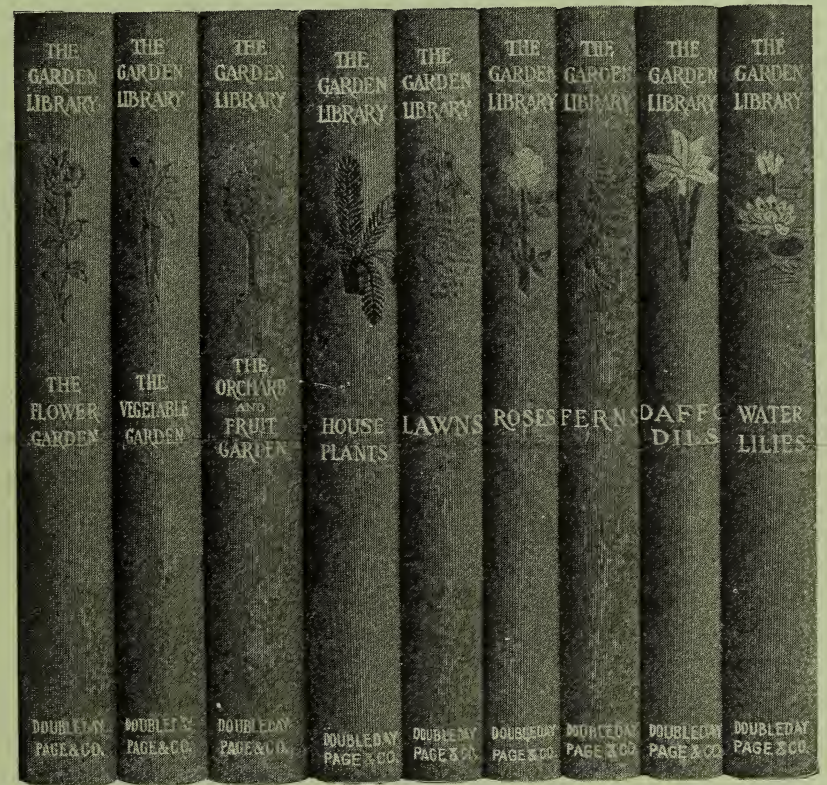

7 HIS library marks a new era in garden literature, as it is the first series 1 of low-priced, practical and beautifully illustrated handbooks on home gardening that has ever appeared in America. These volumes, written by competent authorities on the subjects, are full of good, helpful advice and instruction for all who grow plants and flowers, and for those who take an interest in the maintenance and improvement of the country home grounds.

\section{J. FARMER}

PULASKI, N. Y. 


\section{The Garden Library}

7 HE nine rolumes in The Garden Library are uniformly bound in serviceable

1 green cloth, decorated; size, $5 \times 7 \frac{5}{3}$; profusely illustrated throughout, including many "how to" pictures, planting tables, plans for gardens, etc. As a ready reference work on matters pertaining to the country home and grounds "The Garden Library" should occupy a place on your bookshelf. A brief description and synopsis of contents of each book is herewith given.

\section{The Flower Garden \\ By IDA D. BENNETT}

"A clear and concise summary of crery possible sort of information that might be desired by anyone interested in gardens."-Scientific American.

I. The Location and Arrangement of the Garden. II. Soils. III. Fertilizers. IV. The Hotbed, Coldirame and Sand-box. V. Purchasing of Seeds. VI. Starting Seeds in Flats. VII. Transplanting and Repotting. VIII. House Plants from Seeds. IX. Outside Window Boxes. X. Various Annuals from Seed. XI. Vines. XII. Ornamental Foliage Plants from Seed. XIII. Bulbous and Tuberous-rooted Plants. XIV. Aquatics. XV. The Care of the Summer Rose-bed. XVI. The Hardy Lily-bed. XVII. The Care of Cannas, Caladiums, Dahlias, and Other Bulbs During Winter. XVIII. Hardy Shrubs and Plants for Fall Planting. XIX. Winter Protection. XX. The Care of House Plants in Winter. XXI. Common and English Names of Flowers. XXII. Blooming Season of Various Trees, Shrubs, and Plants. XXiII. A Chapter of Odds and Ends. XXIV. A Chapter of Don'ts.

\section{The Vegetable Garden By IDA D. BENNETT}

This book deals fully with the various regetables that form the staple of the small garden and contains excellent chapters on fertilizers, insecticides and garden tools, all thoroughly up to date and full of the most practical information.

I. The Sanitary and Economic Value of the Kitchen Garden. II. The Location of the Garden. III. Planning the Garden. IV. How to Maintain Fertility. V. The Construction and Care of Hotbeds, Coldframes, and Pits. VI. On the Sowing of Seed. VII. Transplanting. VIII. Tools Which Make Gardening Easy. IX. On the Growing of Various Vegetables. X. Root Vegetables. XI. Vine Vegetables and Fruits. XII. Greens and Salad Vegetables. XIII. Perennial Vegetables. XIV. Storing Vegetables in Winter. XV. The Garden's Enemies. XVI. Fall Work in the Garden.

\section{Orchard and Fruit Garden}

By E. P. POWELL

Deals with the choice planting and cultivation of fruit, fruit-bearing trees and bushes. "This thoroughly practical volume embodies all the latest developments, and sums up all available information on the selection of fruits." -New York World.

Part First - The Orchard. I. The Apple. II. The Apple Varieties. III. The Apple-Handling and Marketing. IV. The Pear. V. The Plum. VI. The Cherry. VII. The Quince. VIII. The Peach. IX. The Apricot. X. The Grape. XI. Citrus Fruits. XII. Figs, Dates, and Olives. XIII. Pineapple, Banana, and other Tropical Fruits. XIV. Undeveloped Fruits. XV. Nuts and Nut Tres.

Part Second - The Fruit Garden. I. The Fruit Garden. II. The Currant. III. The Strawberry. IV. The Raspberry. V. The Blackberry. VI. The Gooseberry. VII. The Cranberry. VIII. Neglected Berries.

Part Third - Cultural Directions. I. Windbreaks, Drainage, Irrigation. II. Pruning, Mulching, Fertilizing, Cover Crops. III. Spraying. IV. Bees, Birds, Fowls, Animals - in the Orchard and Fruit Garden. V. Harvesting and Marketing. VI. Plant Breeding.

\section{Roses and How to Grow Them}

\section{BY MANY EXPERTS}

The only recent book on this most popular of flowers, which deals directly with American practice both outdoors and under glass in all sections of the country.

I. When, Where and How to Plant. II. The Routine of Work. III. Pruning. IV. Insects, Diseases, and

Spraying. V. The Rosarian's Calendar. VI. Roses for Cut Flowers Under Glass. VII. Types and Races. VIII. Roses for Special Purposes. IX. Roses of American Origin. 


\title{
House Plants and How to Grow Them
}

\author{
By P. T. BARNES
}

A manual of the best foliage and flowering plants for home cultivation; their raising from seed and propagation in the window garden,

I. How Other People Have Succeeded. II. Making the Soil Foundation. III. Potting and Repotting. IV. Raising Plants from Seed. V. Propagation by Cuttings, etc. VI. In Sickness and in Health. VII. Bulbs from Thanksgiving to Easter. VIII. The Winter Window Garden. IX. Flowering Plants for House Conditions. X. Koses, Carnations and Chrysanthemums. XI. Cactuses and Other Succulents. XII. Nine Iron Clad Falms. XIII. Foliage Plants other than Palms. XIV. Reliable Ferns for the Dwelling Rooms. XV. Window Gardening Tools and Accessories. XVI. Forcing with Ether. XVII. A Window Gardener's Calendar.

\section{Ferns and How to Grow Them}

\author{
By G. A. WOOLSON
}

The contribution of a nature student who has successfully solved the froblem of growing the native ferns of our Eastern woods. With table of synonomy.

I. The Life of a Fern. II. Where Hardy Ferns Can Be Grown. III. Ferns in the Mixed Border. IV. Rockwork for Ferns, V. Hardy Ferns for Indoor Culture, and How to Select Them. VI. Ferns in the Living Room During Winter. ViI. Fern Rockeries Indoors. VIII. Fern Culture Under Bell Glasses and in the Wardian Case. IX. Exotic Ferns Without a Greenhouse. X. Aerial Fern Culture. XI. Ferns for Special Purposes.

\section{Lawns and How to Make Them}

\section{BY LEONARD BARRON}

The only volume that treats of the making and maintenance of the ornamental lawn from a purely practical standpoint. For the first time the whole truth about lawn seed mixtures is popularly explained.

I. Renovating the Old Lawn. II. How to Make a Lawn Once for All. III. Economical Grading. IV. IIhich Is Better: Turf or Seed? V. The Fine Art of Mowing. Rolling and Watering. VI. How to Feed a Lawn. VII. Solving the Weed Problem, Insects. etc. VIII. The Truth about "Lawn Mixtures." IX. Seed Mixtures for Special Purposes. X. Lawns for Subtropical Regions. XI. The Best Lawn Tools and Their Use. XII. How to Make Lawn Pictures. XIII. The Peculiar Requirements of Putting Greens. XIV. Guide to the Best Lawn Grasses.

\section{Daffodils-Narcissus and How to Grow Them}

\author{
By A. M. KIRBY
}

All that is really worth while about these most popular of spring bulbs written from the standpoint of American conditions.

I. Old-Time and Modern Daffodils and Narcissus. II. Daffodils in the Garden Border. III. Flowering Daffodils in Winter. IV. Water Culture in the House. V. The Commercial Production of Cut Flowers. VI. Naturalizing in the Grass. VII. Miniature Daffodils for the Rock Garden. VIII. The One Insect and One Disease. IX. Straightening Daffodil Nomenclature and Classification. X. The Large Trumpet Daffodils. XI. The Lesser Trumpet, Hoop-Petticoat and Cyclamen-flowered Daffodils. XII. The Medium-crown Hybrids. XIII. The Pheasant's Eye and Poet's Hybrid Narcissus. XIV. The Sweet-scented Jonquils and Campernelles. XV. The Tender Cluster-flowered Narcissus. XVI. The Hardy Cluster-flowered Narcissus. XVII. Double Daffodils and Narcissus of all Groups. XVIII. Some Autumn Flowering Species. XIX. Hybridizing and Raising from Seed.

\section{Water-Lilies and How to Grow Them}

\section{By H. S. CONARD and HENRI HUS}

A practical garden knowledge of the best water-lilies and other aquatics by America's great authority on the family; with cultural details and making of ponds and small gardens.

I. Where Water Gardens Can Be Made. II. Economical Pond Construction. III. Soils and Planting Out. IV. Wintering and Propagating. V. Seed Saving and Starting. VI. Raising New Varieties. VII. The Hardy Water-lilies. VIII. The Tender Day Blooming Water-lilies. IX. The Night Blooming Water-lilies. X. Growing the Giant Victorias. XI. Lotuses. Water Hyacinths and Other Choice Aquatics. XII. Water Gardens Under Glass. XIII. Enemies and Friends. XIV. Pond Surroundings, Windbreaks and Accessory Plants. XV. Water-

lilies for Special Purposes. 

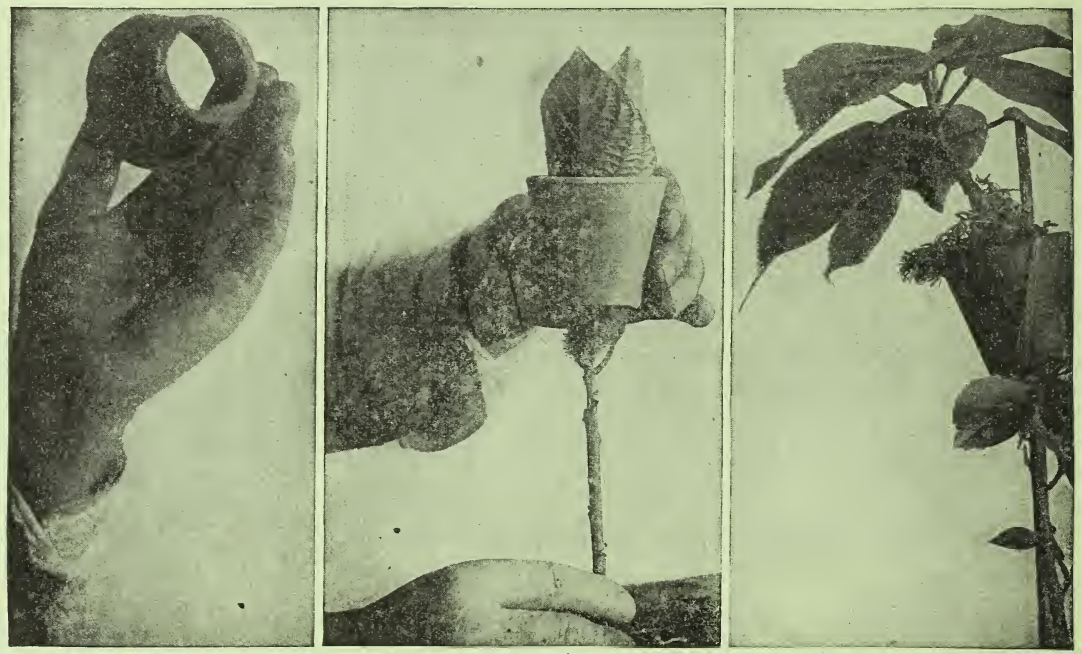

"TOPPING" A PLANT THAT HAS BECOME TOO LARGE

\title{
To Owners of The Garden Library
}

E

VERY owner of "The Garden Library" is entitled to the privileges of the Special Information Department, which we have maintained for years for the benefit of our patrons. This department enables you to secure, without charge, the practical advice and help in your problems of the foremost horticultural and gardening experts in the country.

As a supplementary asset to "The Garden Library" the services of this department will be found of invaluable assistance and far better than any encyclopedia of gardening, because every inquiry receives the individual attention of a specialist on its subject.

We cordially invite your correspondence, and there are positively no restrictions as to the number of questions you may ask.

\section{Price, \$1.10 vol. Postage 7c. extra.}

\author{
L. J. FARMER
}

PULASKI, N. Y. 


\section{ORDER SHEET_Please use this sheet in ordering Plants.}

\section{J. Farmer, Pulaski, Oswego Co., N. Y.}

Please forward by State whether Wanted by Mail, Express or Freight.

Exp. or Firt. Offlce

Name

Post Office

County State

R. R. or Exp. Line.

Forward on or about
Amount Enclosed:

Post Office Order $\$$.

Exp. Money Order $\$ \ldots . . \ldots$.

Draft or Check $\$$.........

Cash

$\$ \ldots \ldots \ldots$

Stamps

Total

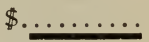

Date.

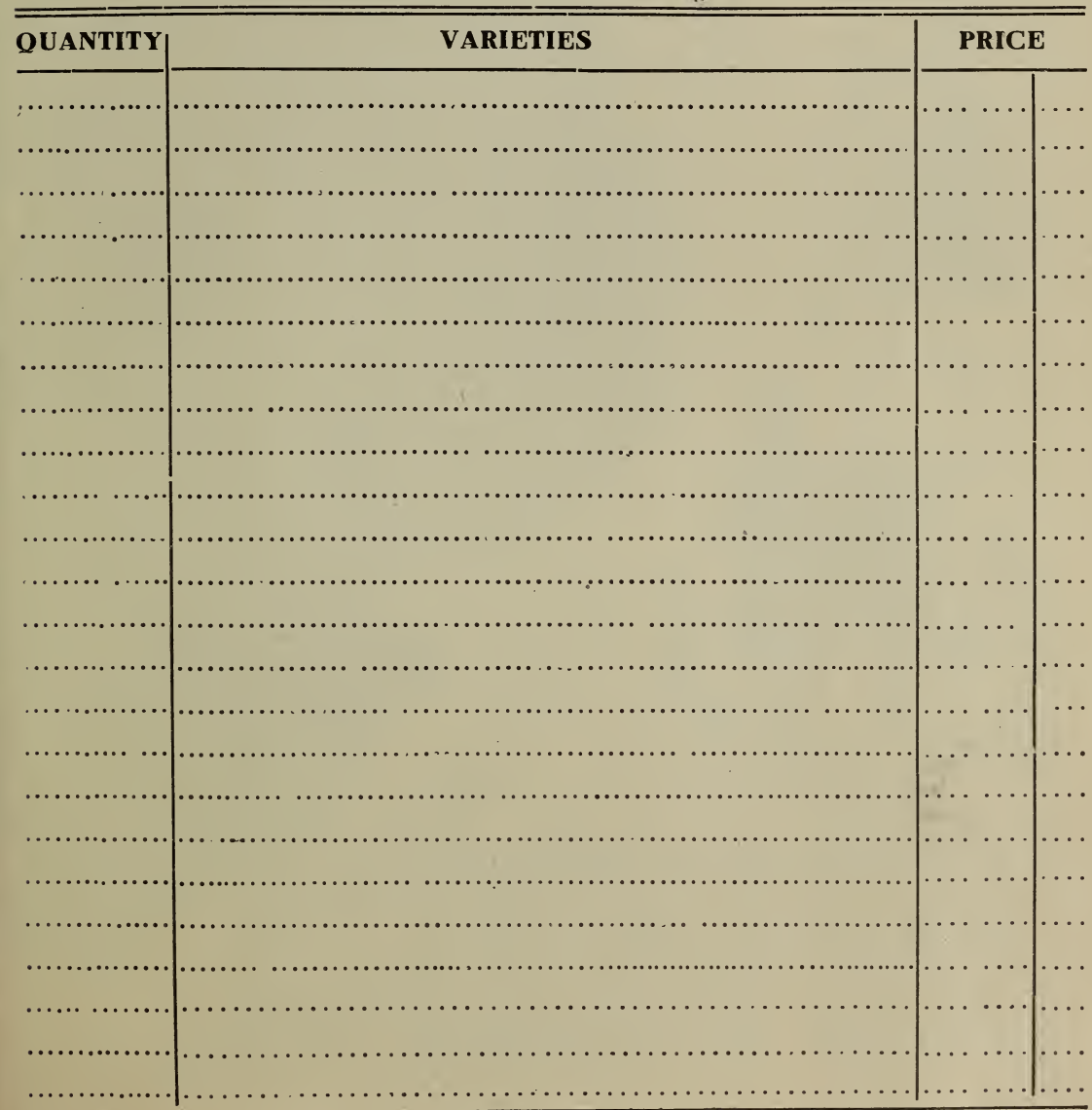




\section{DEMING SPRAYERS}

\section{For All Spraying Conditions}

Two dozen styles of Spray Pumps from the Small Bucket and Knapsack Sprayers to the Barrel, Tank and Power Sprayers for Extensive Orchard Operations, seven styles of Spraying Nozzles and a score of Spraying Appliances.

DEMING SPRAYERS ARE PRACTICAL

Pumps have Brass Working Parts. We make the patent Bordeaux, Demorel and Simplex Nozzles. Used and recommended by leading fruit growers and Agricultural Experiment Stations. They are known as "The World's Best."

A few DEMING SPRAYERS are illustrated below

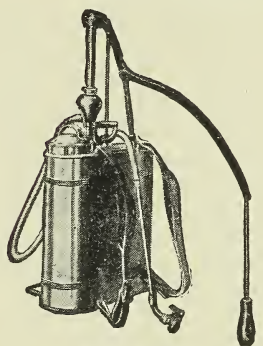

Fig. 675 .

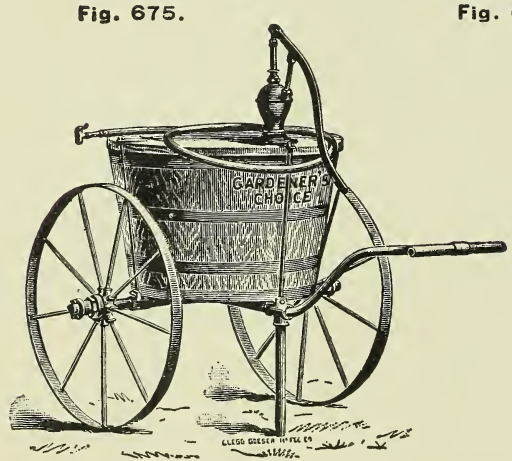

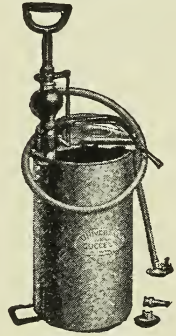

Fig. 662 .

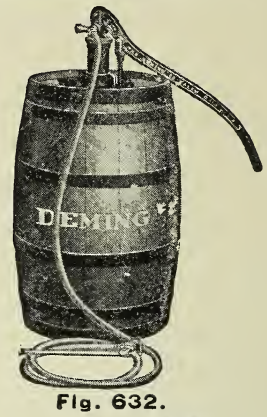

Fig. 651.

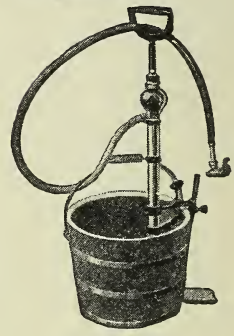

Fig. 689.

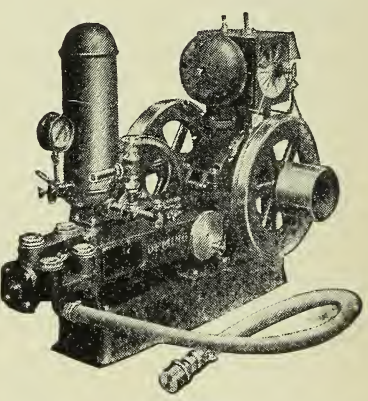

Fig. 656

Fig. 632, The “"Captain," medium price Orchard Sprayer, price _ _ _ $\quad$ - 6.50 675, The "Success" Knapsack for Garden and Vineyard, price _ _ _ _ _ 13.50 662, The "Universal Success," ("Six in One") for Spraying, Whitewashing, Fire Protection, etc.

689. The "Perfect Success" for Gäden and Greenhouse, price _ - - - _ - _ - $\quad 3.50$ 65 1, The "Gardeners" Choice" for Garden and Orchard, price - - - - - $\quad 13.00$ 656, The "Premier" Power Sprayer for large operation, price $\quad$ - - _ - 250.00 We will send complete catalogue of Spraying Machines Free.
A D DRESS
PULASKI, N. Y. 


\section{ONE SPRAYER FREE.}

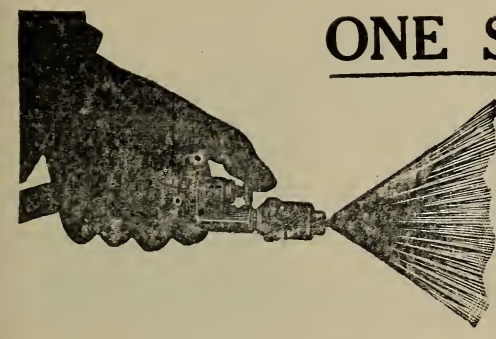

To introduce the new "KANT-KLOG" SPRAYER we offer one free to the first reliable applicant in each locality.

This Sprayer has individual and distinct features found in no other line. The "Kant-Klog" is the

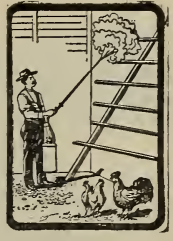
first and only nozzle ever made to give both flat and round sprays and solid streams. The new Spring Hose Cock starts or stops the spray instantly, so preventing waste of fluid.

Is admitted by all to be the best fitted, most satisiactory and fastest selling Sprayer ever on the ma:ket. Custs no mure than the old styles with common fittings. Sprays Trees, Potatoes, Vegetables, Vines, Whitewashing, Disinfecting, and many other uses.

Others are making hundreds of collars with this machine. If you wish either to book the orders in your section, or want a sprayer for your own work, fill cut blank on oppos.te side and we will send special proposition, descriptive matter, spraying guide, etc.

Address, ROCKESTER SPRAY PUMP CO., ROCHESTER, N. Y.

( SEE OFFER ON OTHER SIDE)

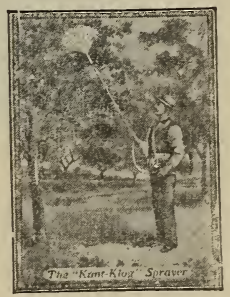




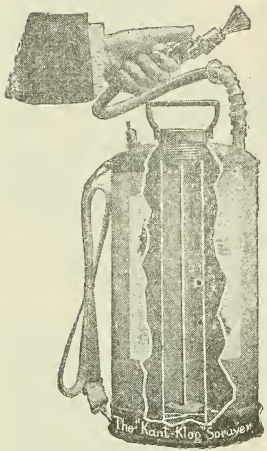

\section{$\$ 1,700$ Made by One Man.}

selling this Sprayer in his home county during spare time.

If you want to book the orlers of your neighbors and friends-or if vou want a Sprayer for your own use-we have a Special Proposition for you.

We offer ONE SPRAYER FREE to the first reliable applicant in each locality.

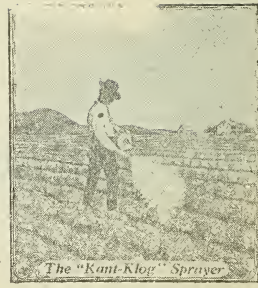

Fill in and send this blank to address given below, stating whether you wish an agency or a sprayer for your own work only.

\section{Name}

\section{P. 0 .}

\section{Street Address}

Do you want Sprayer Agency?
State.

Or for your own work?

Mail this to ROCHESTER SPRAY PUMP CO.,

No. 125

Rochester, N. X. 


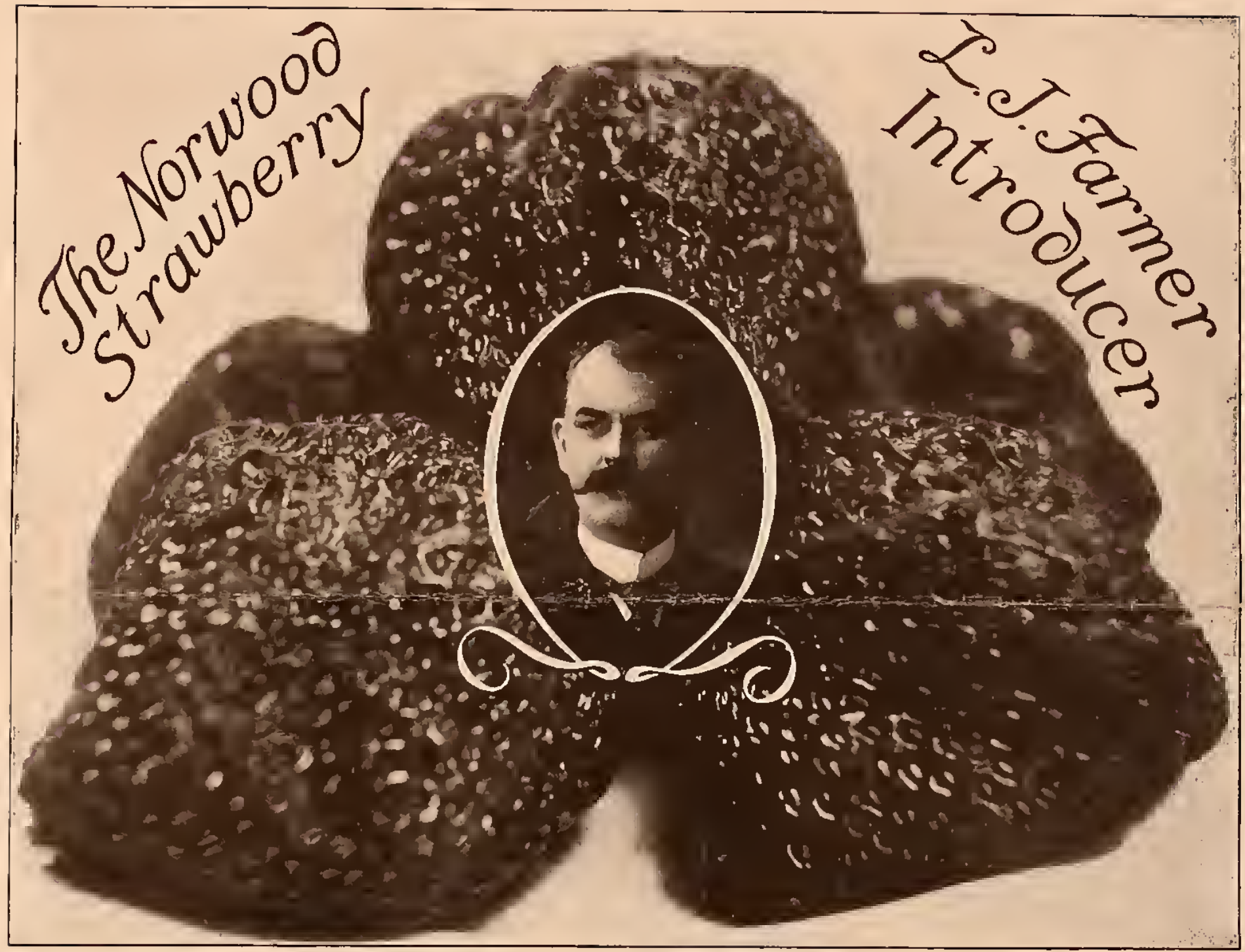

\section{The Originator Says:}

${ }_{6} \mathrm{TT} \mathrm{HE}$ Norwool Strawberry was numed and given the first prize by the Massachusetts Hortichllural society at the exlibition of Igo6. This strawerry is supposed to be a cross hetween the Marshitl and Corsican, as it came up where the Mirshitll had been grown and
near where Corsican wis grown at the silme time.

The Norwool is believed to be the best all-irouml striwberry in existence. The plint is strong and liealthy, uaking a liberal number of strong rumers, but not excessive. The berry is conic ant regular in shipe; not a cockscombed lerry wis fouml this seatson. The

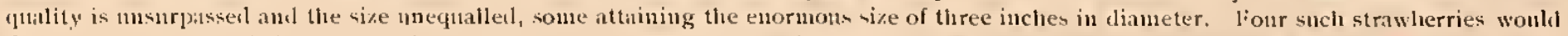
fill a lox and be crowletl. Color, bright red all the way throngi, growing darker with age, is firm, a goonl keeper anl will ship well. Has a perfect blossom and holds its si\%e well throngh the season and remitins in bearing a long time. Picked the first box June isth and the hast one July 18th. 'The largest berries were fonml in matted rows or beds althongh the plints hinl received un extral cuiture.

On iccount of my age $\left(\$_{3}\right)$ and lack of roon to work nj a lirge stock, I feel compelled to put the price high enongin to get something ont of it myself. The price is the same as the Marshall was sold for when first introducesl, antal as the Norwoorl is a much better beirer, I feel

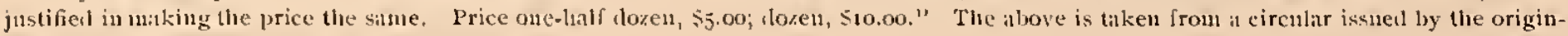
ator before we purchasel the berry from lim.

\section{CON'IRA C'T}

In consideration of the reduced price at which I buy plants of the Norwood strawberry, viz:--25 plants for $\$ 10.00$, I agree to not sell or offer for sale or give away any plants of this variety during the fall and spring season of 1908 and 1909 for less than the retail price, then asked by the introducer,

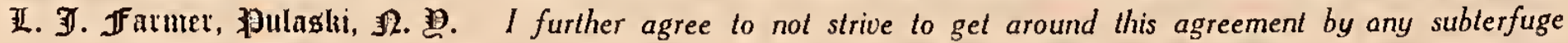
or inunuendo, but to observe strictly the golden rule and do as I would like to be done by. 
We never lave been so powerfully inupressed with any strawberry as we have been since first seeing tlie plotograph and reading the description of the Norwood in the Anerican Cnltivator, of Boston, and also in Mr. White's circillar, sent out tlis winter. Tlie berry, originated with N. 13. White, of Norwoul, Mass., was lyronglit to onr attention hy him several years ago, but it is nothing mnconnuon for us to get letters fron originators abont new berries and we passel his letter by liglitly. As soon as we saw the photograpli, we began negotiations to liandle the berry on connission which 11ltimately led to our purchasing it ontriglit. The deal was not consumnated lowever in tinne to give tlie proper attention in our catalogne for this year, al- thongl we are selling the plants to niany leading strawberry growers The entire stock of Norwood is but fonr square rods, just one-fortietli of an acre of plants, only a few thonsand, and yet we pay Mr. White $\$ 250.00$ in crsli for the plants, which is at the rate of srooo0.00 to the acre, a pretty good price for a strawberry bed. 'There is no tradk deal nor private bargain in any way. I have already paid Mtr. Wlite $\$ 100.00$ and will have to plank down the \$150.00 alditional before a plaut is ding. I sliall go to Boston and Norwood as soon as it thaws sufficiently and dig the plants, slipping all plants direct to customers irom there, that is possible.

\section{Reduced Prices for Norwood (under conditions)}

The price of the Norwood is \$1o per dozen. We sell single plants at $\$$ i each. To those who will agree to not undersell ns next year (see contract) we agree to sell 25 plants for $\$ 10$. Those wlio pay' $\leqslant 1$ eaclı, sio per (lozen, can ask any oll price next year they wisli, cin sell for $25 \mathrm{c}$ per dozen if they are foolish enougli to to it. If yon want 100 plants they will cost you $\$ 40$, 1000 plants for $\$ 400$ etc. (under couclitious).

\section{How to Get the Norwood for $\$ 5$ to $\$ 10$ per 1000}

Sign the contract, send it to us, with $\$$ Io aud we will send you 25 plants by mail, packed so they will grow. Set these in rich soil keep stirred ant all weets ont. Train the rmmers and set each youmg plant so it will root quickly. Toll call raise froll 1000 to 2500 Norwood in one senson from the 25 plants, depending on your skill. These plants liave cost yoll a little work and at the rate of st to \$10 per I000, which is not an extravagant price for any gool plants.

\section{This Woman Has}

A lady writes, "l send you Sio for 25 plants of your Norwood strawberry. I lave confidence in you as I never was huncoed when buy ing plants of yon. My neiglibors are slow to takenp with new things, unless it is sonie worthless novelty offerenl by sonie tree agent. They won't pay sinch a price for strawberry plants now but they will all want them in two or three years and I am going to be ready to snpply iliel1. I an1 going to set these plants in ricli soil, 6 feet apart eacli

\section{We will grow the Norwood}

\section{for you on Contract}

Nurserymen and others who do not wish to grow their own plants can have then1 grown by 11 on contract. Onr wholesale price this coning fall and also spring of 1909 will be $\$ 25$ per 1000 , the retail price will undoubtedly be \$I per dloz.; \$5 per Ioo.

\section{The Norwood will be Pushed}

We believe the Norwood is the greatest strawberry of the day and we purpose to pnsh it by advertising next year as no other strawberry has ever been pushed. It will be taken up by all leading nurserymen. The demand for plants will be enormons for many years. This will be due, first to its great merits and second to the fact that we purpose to advertise it in the Horticultural and Agricultural papers as no other strawberry has ever been advertised. Our ad of this berry in the National Nurseryman for March was the largest advertisement ever inserted for a strawberry in any paper as well as the most attractive. Our advertisement in Marth 7 th $_{1}$, issue of Riral New Yorker cost over $\$ 200$, the largest price ever paid for a single alvertisement of anv strawberry. It is our purpose to spend $\$ 5000$ next winter in advertísing this berry in the agricultural press. MIr. S. H. Warren, of Weston, Mass., the veteran strawberry grower and nurseryman writes us that our sales of this berry will he enormons. Mr. Warren was in negotiations for the control of the Norwood at the same time as we were and came pretty near getting the plu11 away from us. He will pissls the herry in his catalogue for all it is wortl next spring, so will Mattlew Criwford, of Ohio, the Dean of Strawberry Authorities, Henry Dreer, the great seedsman and many others, all of wliom liare sent in their orders for plants. have to pnt 11pon tlien tlie first year. 2500 plants to grow from 25 Norwoor is not an extralyant estimate. When tle Crescent was firstintroduced, il party grew 10,000 from 12 in one season; he set then to feet apart eacli way and they filled the space. Don't yon wish you hat bouglit a lozen or so of the linbach, Marshall or Glen Mary, when they first came ont? You will liave to have the Norwoou some time, wliy not get them now?

\section{It All Figured Out}

way and take good care of then1. I expect to raise 2000 plauts. Next spring I anl going to liave an acre of gronnd ready for them and set then about the sanne listance apart, as the plants will be fresh ding and set ont same day. I think I can get roo plants from encli one set, wlicl will make nue 200,000 plants from the original 25 plants in two years. If the price is then only $\$ 5$ per 1000 , this will amont to \$rooo.'

\section{The Originator}

The aged originator of the Norwood strawberry is naned Nathan 13. White. He lives at 314 Naliattan St., Norwool, Mass. He has produced some wonderful grapes as well as this great strawberry. He writes me that althongl I pay lim \$25o.oo for this berry, were it not for lis age, liis lack of room to work 11p a lig stock and other conditions beyond lis control, lie would not part witli this berry for four times the price paid.

\section{Price of Cuts}

The price of lialf tone cuts, sliowing the cluster of Norwood strawberries salue as on this sheet is $\$ 6.45$ for original half tones and $\$ 2.15$ for electros. We lave electros from a wood cilt which ir. Warreu had uade when lie expected

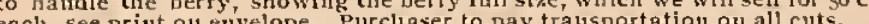

\section{Has Confidence in L. J. Farmer}

Mr. T. A. Kerr, of Durango, Colorado, when seuding $\$ 40.00$ to us for 5000 plauts of the Oswego strawberry writes as follows: "1 here send you an orcler Tor 5000 of your Oswego strawiorry plants as you speak wery highy of hell were wrell pleased."

We well know that not everybody was as well pleased witl the Rouglı Rider as was MIr. Kerr, but the Rough Rider is still a grant berry with 11 and is grown in many places and will be for years. It is the best canning berry in existence to-clay, as well as extremely late. No one ever accused me, however, of palming off an old berry under a new nanle or of any but the best intentions when $\mathrm{I}^{-}$sent out tlie Rongl Rider strawberry. To those who liave confidence in me and wish to know what I think of the Norwood, I will say that I hare never seen it in fruit and know notling of it except what the originator and otliers say. If I dirl not think it the grandest herry in existence, I wonld not go into it nuyself as I havedone. This is enongli for me to say. Address all orders and correspondence to

\section{The Plum Farmer Raspberry}

The greatest money maker of the day. Yields nearly 4000 qnarts, bringing $\$ 468.80$ to the acre. Read the following letters:-

J. J. Farmer, Pulaski, N.Y. North Stoni ngton, Col11,, March 3d, 1907, flum Farnerid Parmer:-1 feel very gratefinl to you that you introduced the Plumu Farmer Raspberry. I bollglit ioo of yoll, tliree years ago, and have fruited it twice and liave an acre of thenl1 to fruit this year. It is the greatest raspberry

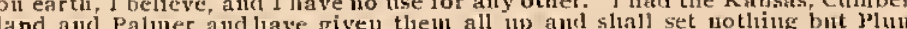

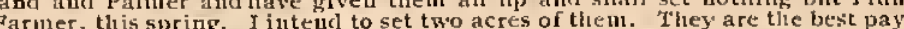
ing of anythiug in the fruit line thiat $I$ liave ever strilck; they pay ure better thian strawberrics. I sold, this past silnmer, from 64 square rods of Plun1 Farmer $\$ 187.53$ wortli. Thley a veraged me a little over $12 \mathrm{C}$ per quart.

$$
\text { CHARLES } k \text {. CHAPMAN. }
$$

Nortli Stouington, Col11, Marcli $66,190 \%$.

Ir. J. Farmer, P'ulaski, N. Y.

The

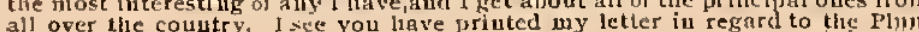

Farmer Raspberry anll I hope it may help you to sell a good tuany plants. The best part of it is that it is all true and I aun getting many inglinies in regard to it. Just liad oue from Mr. Richmond, of Gencra, Ohio. Your advertisentent

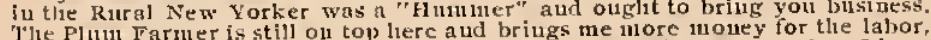

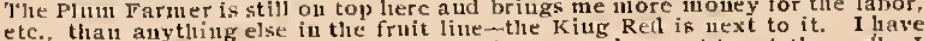

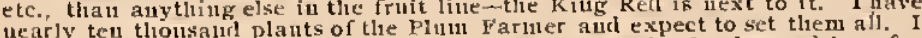

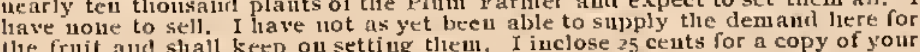
book on Berry Fruits which please send me when published. Wishiug your a prosilterons season in your busiuess, I remain. Yours sincerely,

Box 81, North Stouington, New Loudon County, Coun.

No lirnit Grower or Nurseryman can afford to do withont this grand l3lack Cap. We never sold so many dollars worth of any fruit plants as we are selling this spring, as high as 10,000 to one party in the great liack Cap evaporating sections. Price of strong plants; 5oc per dozen; \$I.50 per 100; \$10.00 per 1000 . 


\section{White Wyandottes}

We have about 25 fine White Wyandotte cockerels we will sell for $\$ 2.50$ each. Two pullets and one cockerel (trio) fo- $\$ 6$. Order at once.

Our White Wyandotte eggs are very fertile. We keep plenty of males and do not allow our hens to lay much until spring. You cannot beat them anywhere. Price of eggs from best selected pens, \$2 per I $3 ; \$ 3$ per 26; \$8 per Ioo; 2nd best pens, \$I yer I3; \$I.75 per 26; \$5 per Ioo.

\section{Eggs For Hatching}

We can supply eggs of the following list of poultry, secured from breeders in this locality: Crystal White Orpingtons (Kellestrauss strain), Anconas, Houdans, Buff Orpingtons, Pekin, White Muscovy, Rouen and Indian Runner Ducks, Columbian, Wyandotte, etc. Write for prices.

L. J. Farmer, Pulaski, N. Y.

\section{Plants}

On early orders and until our stock is reduced, we will sell 5000 Plum Farmer or 5000 Columbian for $\$ 50$. We reserve the right to withdraw this offer at any time.

We have 25,000 plants each of Oom Paul and Barton's Eclipse strawberry plants we will sell at 25c per doz, $50 \mathrm{c}$ per Ioo, and $\$ 5$ per rooo. We mention these varieties here because they were overlooked in writing the body of the catalogue.

\section{Free Bulbs}

if you will send the names of five or ten of your friends, with their addresses plainly written, we will send you 6 large Orchid Gladiola bulbs free. We prefer a few good names rather than a long list of undesirable ones. Send $5 c$ for postage on bulbs. Every person who orders goods from this catalogue to the amount of $\$ 2$ or more, can have 6 large Orchid Gladiola bulbs absolutely free and need not send postage.
The Fruitman and Gardener.

Published at Mount Vernon, Ia., is on $t$ of the best pappers publisheri in the interest of fruit growers, especialı, for berry growers. L. J. Farmer will be a regular contributor for this paper during the coming season. The subscription price is 5oc per year and it is clieap at that price, single numbers being soinetimes worth several times the annual subscription price to any fruit grower. By special zrrangement with the publishers we are enabled to supply the paper one year for 25c. Send your quarter today. Address L. J. Farmer, Pulaski, N. Y.

\section{The Hastings Potato}

Is such a vigorous grower that it 15 practically bug proof. This is the year of all years to plant potatoes. The Hastings is the variety to plant for main crop. You might better pay four times as much for Hastings as for Carman, Rural New Yorker and other kinds.

\section{Farm Employment Agency}

We will endeavor to supply help to farmers and secure positions for men and women on farms. Farmers who need help should correspond with us. People who want positions on farms should write us stating their qualifications, wages asked, etc. Address The Farmer Employment Agency, Pulaski, N. Y.

Better Than Money in the Bank

If you buy plants of Early Ozark,Plum Farmer, Columbian, Snyder, Cuthbert, Idaho, Royal Purple or Perfection, put them on good land and give good care, you have a better investment than in anything we know of and just as safe as a government bond.

\section{Write Plainly}

Nothing is so important in ordering goods by mail as good penmanship. If you cannot write plainly, get some good penman to write your letters for you. Thousands of dollars are lost in the mails every year, due to poor penmanship.

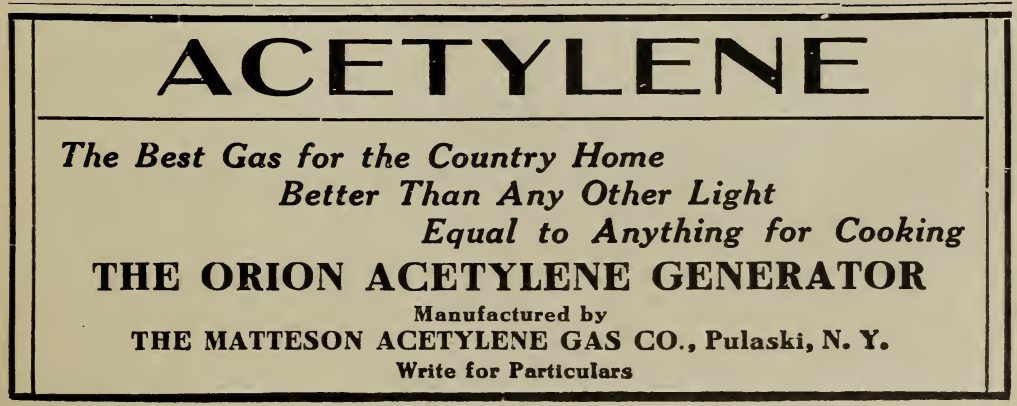




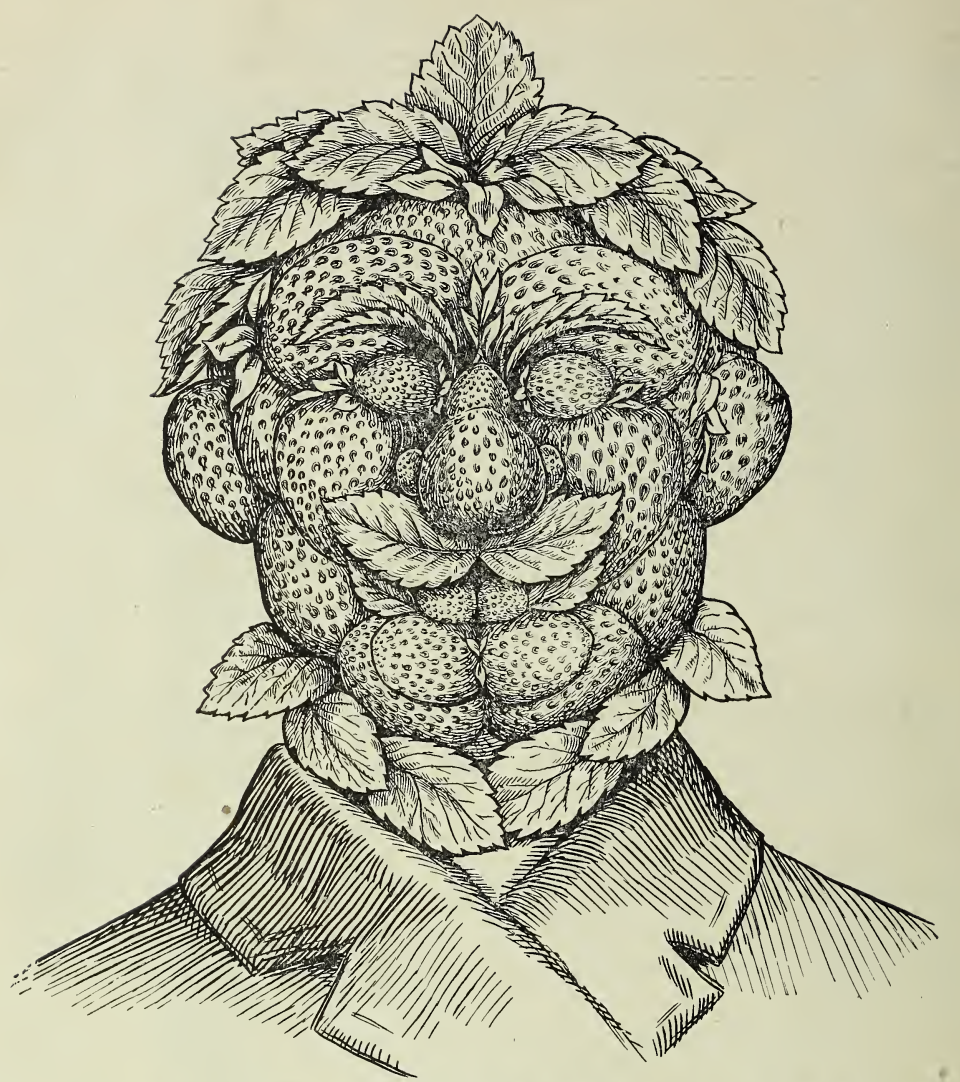

\section{THE STRAIWBERRYMAN} of PULASKI, N.У.

\section{STRAWBERRY SECRETS}

The secrets of successful strawberry growers, as well as all other matters pertaining to strawberry culture, are fully explained in the new (1909) edition of

"FARMER ON THE STRAWBERRY"

a real book, not a catalogue, by Lawrence Jones Farmer, the Strawberry Man of Pulaski, N. Y., who has worked 27 years among strawberries. It not ony treats of strawberries but of raspberries, blackberries, etc; 64 pages, illustrated. "Worth its weight:in gold," but costs only $25 \mathrm{c}$ postpaid. MONEY BACK IF NOT SATISFIED.

Some people get up a catchy, misleading catalogue and advertise it free, as a hook on strawberry culture. "Farmer on the Strawberry" is a treatise, with no advertising of our or anybody's business; just tells the story of strawberry culture in plain words. Send your quarter today. Address

I. J. FARMAR, Pulaski, Oswego Co., N. Y. 